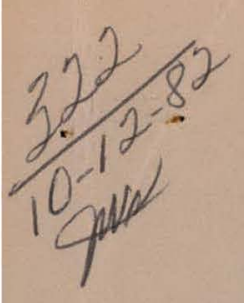

\title{
PROPERTIES OF FORMULA 127 GLASS PREPARED WITH RADIOACTIVE ZIRCONIA CALCINE
}

\section{EXXN NUCLEAR IDAHO COMPANY, Inc.}

\section{DEPARTMENT OF ENERGY}




\section{DISCLAIMER}

This report was prepared as an account of work sponsored by an agency of the United States Government. Neither the United States Government nor any agency Thereof, nor any of their employees, makes any warranty, express or implied, or assumes any legal liability or responsibility for the accuracy, completeness, or usefulness of any information, apparatus, product, or process disclosed, or represents that its use would not infringe privately owned rights. Reference herein to any specific commercial product, process, or service by trade name, trademark, manufacturer, or otherwise does not necessarily constitute or imply its endorsement, recommendation, or favoring by the United States Government or any agency thereof. The views and opinions of authors expressed herein do not necessarily state or reflect those of the United States Government or any agency thereof. 


\section{DISCLAIMER}

Portions of this document may be illegible in electronic image products. Images are produced from the best available original document. 
Printed in the United States of America

Available from

National Technical Information Service

U.S. Department of Commerce

5285 Port Royal Road

Springfield, Virginia 22161

NTIS Price Codes: Printed Copy $\mathrm{A03}$

Microfiche $\mathrm{A} 01$

\section{DISCLAIMER}

This book was prepared as an account of work sponsored by an agency of the United States Government. Neither the United States Government nor any agency thereof, nor any of their employees, makes any warranty, express or implied, or assumes any legal liability or responsibility for the accuracy, completeness, or usefulness of any information, apparatus, product or process disclosed, or represents that its use would not infringe privately owned rights. References herein to any specific commercial product, process, or service by trade name, trademark, manufacturer, or otherwise, does not necessarily constitute or imply its endorsement, recommendation, or favoring by the United States Government or any agency thereof. The views and opinions of authors expressed herein do not necessarily state or reflect those of the United States Government or any agency thereof. 
ENI CO-1120

Distributed Under

Categor y: UC-70

Nuclear Waste Management

ENICO- -1120

DE8 3000790

PROPERTIES OF FORMULA 127 GLASS PREPARED WITH

RADIOACTIVE ZIRCONIA CALCINE

B. A. Staples

D. A. Pavlica

H. S. Cole

September 1982

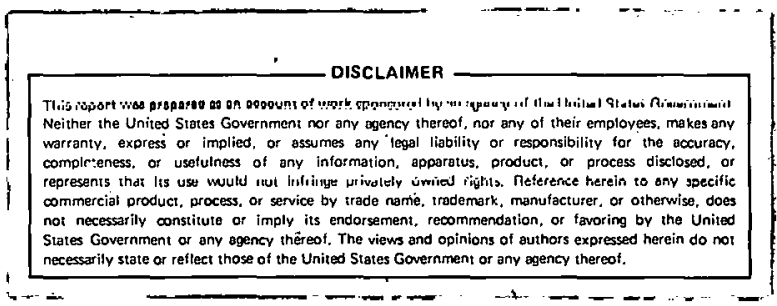




\section{ACKNOWLEDGEMENTS}

The authors wish to acknowledge the assistance of and therefore express appreciation to personnel of the following organizations;

Custom Fuel Processing Group of the ENICO Production Department for providing laboratory space for leach testing of radioactive glass samples,

Spectrochemical and Spectroscopy Groups of the ENICO Analytical Chemistry Department for performing chemical analyses and radioassay on glass samples and leachates,

Production Support Analysis Group of ENICO Production Support Analytical Department for remote cutting and constant weighing of radioactive glass samples,

EG\&G Materials Technology Branch for performing scanning electron microscopic analys is of glass samples,

EG\&G Hot Cells Branch for providing hot cell space for and performing the preparation and rough sampling of glass samples prepared with radioactive calcine. 


\section{ABSTRACT}

Formula 127 glass has been developed to immobilize ICPP zirconia calcine. This glass has been prepared remotely on a laboratory scale basis with actual radioactive zirconia calcine retrieved after ten years of storage from Bin Set 2. The aqueous leachability of the glass produced was investigated and compared through application of the MCC-1, MCC-2 and Soxhlet leach tests with that of Formula 127 glass prepared with simulated calcine. The solid state properties of the glasses prepared with actual and simulated calcines were also measured by electron spectroscopy for chemical analys is (ESCA) and scanning electron microscopy energy dispersive X-ray (SEM-EDX).

Based on the application of these leaching tests and analys is techniques the properties measured in this study are similar for 127 glass prepared with either simulated or radioactive calcine. 
Formula 127 glass has been prepared on a laboratory scale with radioactive zirconia calcine retrieved from Bin Set 2. Because of the radioactivity and dispersibility of the calcine the glass was prepared and sampled in hot cells.

Samples of the radioactive glass were subjected to the MCC-1 and MCC-2 static leach tests, the Soxhlet leach test, and a four-level factorial design leaching experiment. The results obtained from applying these leach tests to the radioactive glass and to the same glass prepared with simulated zirconia calcine in the laboratory, or to glass prepared with simulated calcine in the pilot plant scale melter are generally similar.

Samples of the radioactive 127 glass, 127 glass prepared in the 1 aboratory with simulated calcine, and glass prepared in the pilot scale melter with simulated calcine were subjected to ESCA and SEM-EDX analysis. The results obtained from these analyses indicate that bulk compositions of all three glasses are similar, but with some differences in the minor elements present. However, some of these differences can be attributed to differences in chemical composition between simulated and radioactive zirconia calcine. Calcium fluoride crystallinity was present to a much greater degree in the melter glass, probably resulting from its slower cooling rate, than the laboratory produced glasses. In general, surfaces of these glasses, subjected to the MCC-1 leach test were depleted or enhanced in the same elements. 
ACKNOWLEDGEMENTS ....................... $i_{i}$ ABSTRACT .........................

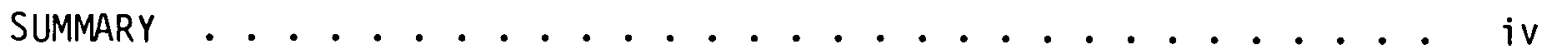

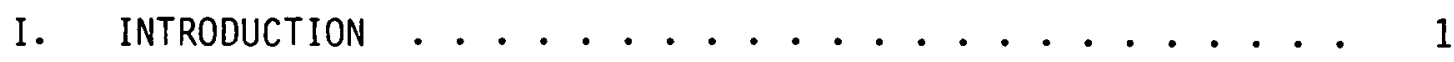

II. USE OF GLASS TO IMMOBILIZE ZIRCONIA CALCINE . . . . . 4

II I. REMOTE PREPARATION OF GLASS TO IMMOBILIZE RADIOACTIVE ZIRCONIA CALCINE .......... 6

IV. LEACHING PROPERTIES OF GLASS SAMPLES $\ldots \ldots \ldots$

A. Specimen Cleaning before Leaching ......... 9

B. The Soxhlet Leach Test ............ 9

C. The MCC-1 Low Temperature Static Leach Test . . . . . . 9

D. The MCC-2 High Temperature Static Leach Test . . . . 10

E. Factorial Design Experiment ......... 10

F. Chemical Analysis and Radioassay of Leachates and Dissolved Glasses ............ 10

G. Soxhlet Leach Test Results ........... 13

H. MCC-1 and MCC-2 Static Leach Test Results ...... 13

I. Factorial Design Experiment Results ........ 20

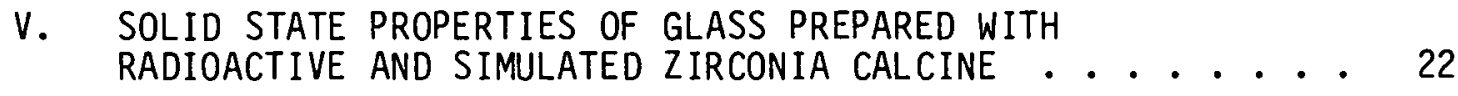

A. Surface Analys is by ESCA ........... 22

B. SEM-EDX Analysis ................ 30

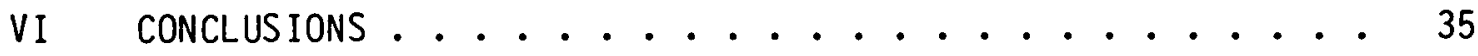

A. Leaching Studies ............. 35

B. Solid State Studies............... 35

VII. REFERENCES ....................... 37 APPENDICES

A. CALCULATION OF LEACHING PRUPERTIES OF 127 GLASS . . . . . 39

B. CALCULATIONS FOR THE FACTORIAL DESIGN EXPERIMENT ...... 41 


\section{FIGURES}

1. Hot Cell Activities for the Preparation and Sampling

of Radioactive 127 Glass . . . . . . . . . . . . 8

2. Two Thousand Second Gamma Scan of 1-mL Aliquot from 100-mL

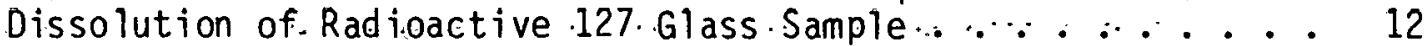

3. Total Mass Loss Rates From 127 Glass Samples Subjected to MCC-1 and MCC-2 for 3, 7, 14 and 28 Days . . . . . . .

4. Cesium Loss Rates From 127 Glass Samples Subjected to MCC-1 and MCC-2 for 3, 7, 14 and 28 Days . . . . . . . . . 18

5. Strontium Loss Rates From 127 Glass Samples Subjected to MCC-1 and MCC-2 for 3, 7, 14 and 28 Days . . . . . . . 18

6. Calcium Loss Rates From 127 Glass Samples Subjected to MCC-1 and MCC-2 for 3, 7, 14 and 28 Days ..........

7. Plutonium Loss Rates from Radioactive 127 Glass Samples Subjected to MCC-1 and MCC-2 for 3, 7, 14 and 28 Days . . . .

8. ESCA Spectra of Vacuum Fractured 127 Glass Prepared with Simulated Zirconia Calcine in the Pilot Scale Melter and in the Laboratory . . . . . . . . . . . . . .

9. ESCA Spectra of Un leached Cut 127 Glass Prepared with Simulated Lirconia Calcine in the Pilot Scale Melter and Prepared with Radioactive Calcine in the Laboratory . . . . .

10. ESCA Spectra of Un leached Cut 127 Glass, Prepared with Simulated Zirconia Calcine in the Pilot Scale Melter and Prepared with Radioactive Calcine in the Laboratory, after Removing Approximately $50 \AA$ of the Surface by $A r$ Ion Milling

11. ESCA Spectra of the MCC-1 Leached Surface of 127 Glass Prepared with Simulated Zirconia Calcine in the Pilot Scale Melter and Prepared with Radioactive Zirconia Calcine in the Laboratory ..................

12. Depth Profiles of MCC-1 Leached Formula 127 Glass Prepared with Simulated Zirconia Calcine in the Pilot Scale Melter and Prepared with Radioactive Calcine in the Laboratory . . .

13. ESCA Spectra, at a Depth of $800 \AA$, of MCC 1 Leached 127 Glass Prepared with Simulated Zirconia Calcine in the Pilot Scale Melter and Prepared with Radioactive Calcine in the Laboratory 
I. Physical Properties of As-Produced and Retrieved Radioactive Zirconia Calcine Samples ............. 2

II. Major Constituents of Retrieved and Fresh Product Radioactive Zirconia Calcine, wt\% .......... 3

III. Composition of Formula 127 Glass Frit . . . . . . . . . 4

IV. Composition of $30-\mathrm{cm}$ Calciner Run \#80 Product . . . . . . 5

V. Principal Radionuclides Present in Radioactive Zirconia Calcine Retrieved from Bin Set 2......... 6

VI. Elements Determined in Glasses and Leachates . . . . . 10

VII. Components of 127 Glasses Subjected to Leach and Solid State Characterization .......... 11

VIII. Total Mass Loss Rates and Normalized Elemental Loss Rates From 127 Glass Subjected to Soxhlet Leach Test . . . . . 13

IX. Total Mass Loss and Normalized Elemental Losses From Glass Prepared with Actual Radioactive Zirconia Calcine and Subjected to Static Leach Tests, $\mathrm{g} / \mathrm{m}^{2}$..........

X. Total Mass Loss and Normalized Elemental Losses From Glass Prepared with Simulated Zirconia Calcine in the Laboratory and Subjected to Static Leach Tests, $\mathrm{g} / \mathrm{m}^{2}$.......... 15

XI. Total Mass Loss and Normalized Elemental Losses From Glass Prepared with Simulated Zirconia Calcine in the pilot scale melter and Subjected to Static Leach Tests, $\mathrm{g} / \mathrm{m}^{2}$........ 16

XII. Matrix of Factorial Design Experiment Based on MCC-1

Static Leach Test..................... 21

XIII. Bulk Compositions of 127 Glass Prepared with Simulated Calcine as Determined by ESCA . . . . . 28

XIV. Unleached Diamond Cut Surface Composition of 127 Glass ...................... 29 


\section{TABLES (continued)}

XV. Far Surface Composition of Un leached and MCC-1 Leached 127 Glass Prepared with Either Simulated or Radioactive

Zirconia Calcine as Determined by SEM-ËDX . . . . . . . 33

XVI. Far Surface Composition of High and Low $\mathrm{Ca}$ and $\mathrm{F}$ Content Areas as.Determined b.y SEM-E.DX in.127. Glass. Prepared in the Pilot Scale Melter, wt\%

B-1 Yates Algorithm for Factorial Design Experiment ..... 41 


\section{INTRODUCTION}

At the Idaho Chemical Processing Plant (ICPP), radioactive wastes from the reprocessing of nuclear fuels have been solidified by calcination since 1963 in the Waste Calcination Facility (WCF). 1 Presently, over $2000 \mathrm{~m}^{3}$ of calcined high-level defense waste is being stored on site in 500-year integrity stainless steel bins.2 Calcined wastes from the reprocessing of zirconium alloy-clad fuels (zirconia calcine) make up much of these solid wastes stored at ICPP.2 Many physical and chemical properties of zirconia calcine retrieved from $B$ in Set 2 after ten to twelve years of storage have been determined. 3 Table I summarizes important physical properties of zirconia calcine, which is unique in that it contains $\mathrm{Al}, \mathrm{Ca}, \mathrm{F}$, and $\mathrm{Zr}$ as major constituents and $\mathrm{B}, \mathrm{Na}$, $\mathrm{NO}_{3}$, Fe, and mixed fission products as minor constituents.

Calcine may be unsuitable as a final waste form because of its dispersability and the demonstrated aqueous leachability of fission products from its structure.4,5 It has therefore been proposed that calcine be converted to a form which may be more suitable as a waste form such as glass for final disposal. The conversion of zirconia calcine to Formula 127 glass is potentially suitable for this purpose.6,7,8 Thus to provide information to support the practicality of this conversion, leaching. and solid state characterization of Formula 127 glass prepared on a laboratory scale with retrieved calcine has been performed. 
TABLE I

PHYSICAL PROPERTIES OF AS-PRODUCED AND RETRIEVED

RADIOACTIVE ZIRCONIA CALCINE SAMPLES

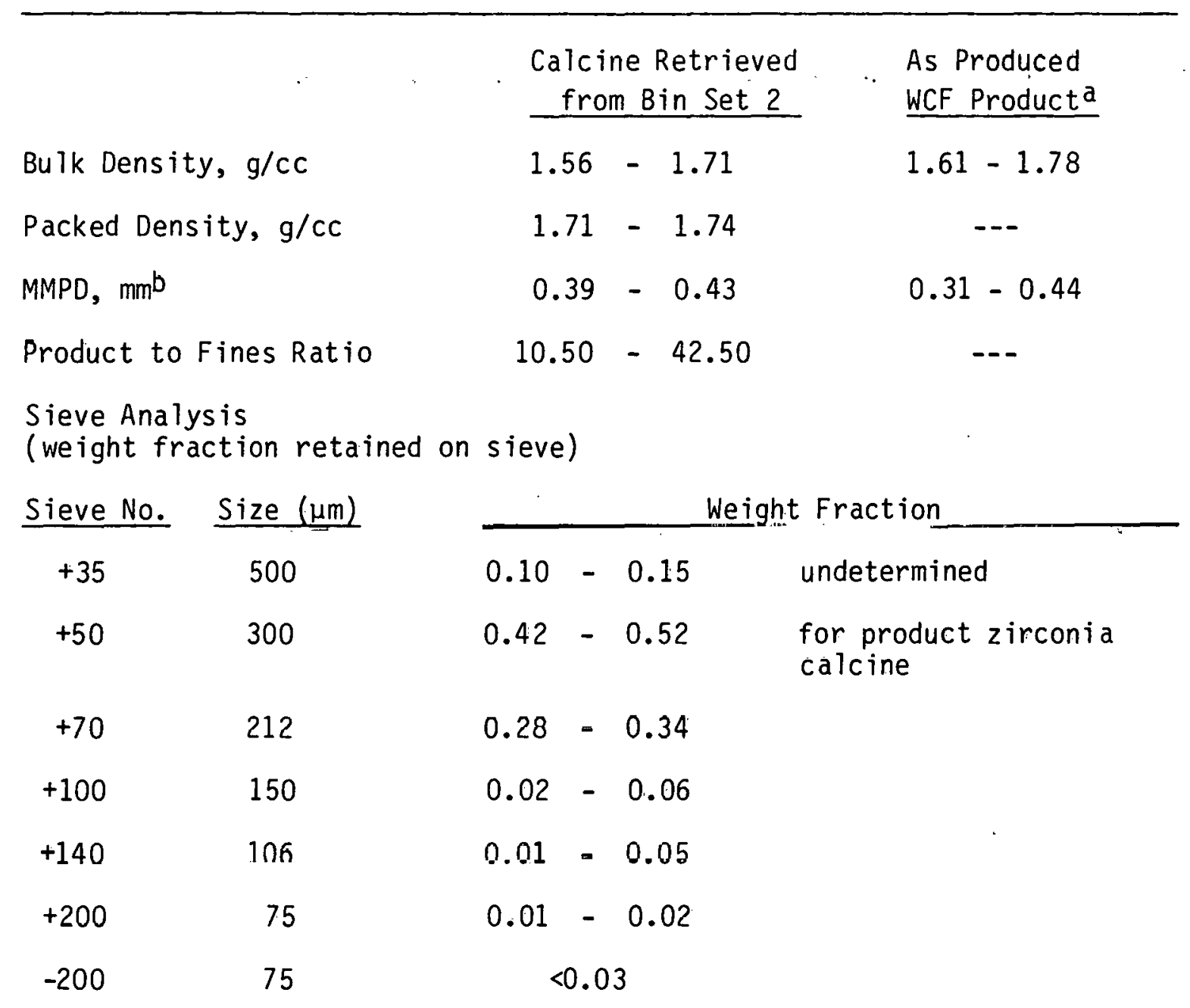

a Unpublished data from the second and third WCF Campaigns.

b Mass median particle diameter. 
TABLE II

MAJOR CONSTITUENTS OF RETRIEVED AND FRESH

PRODUCT RADIOACTIVE ZIRCONIA CALCINE, WT\%

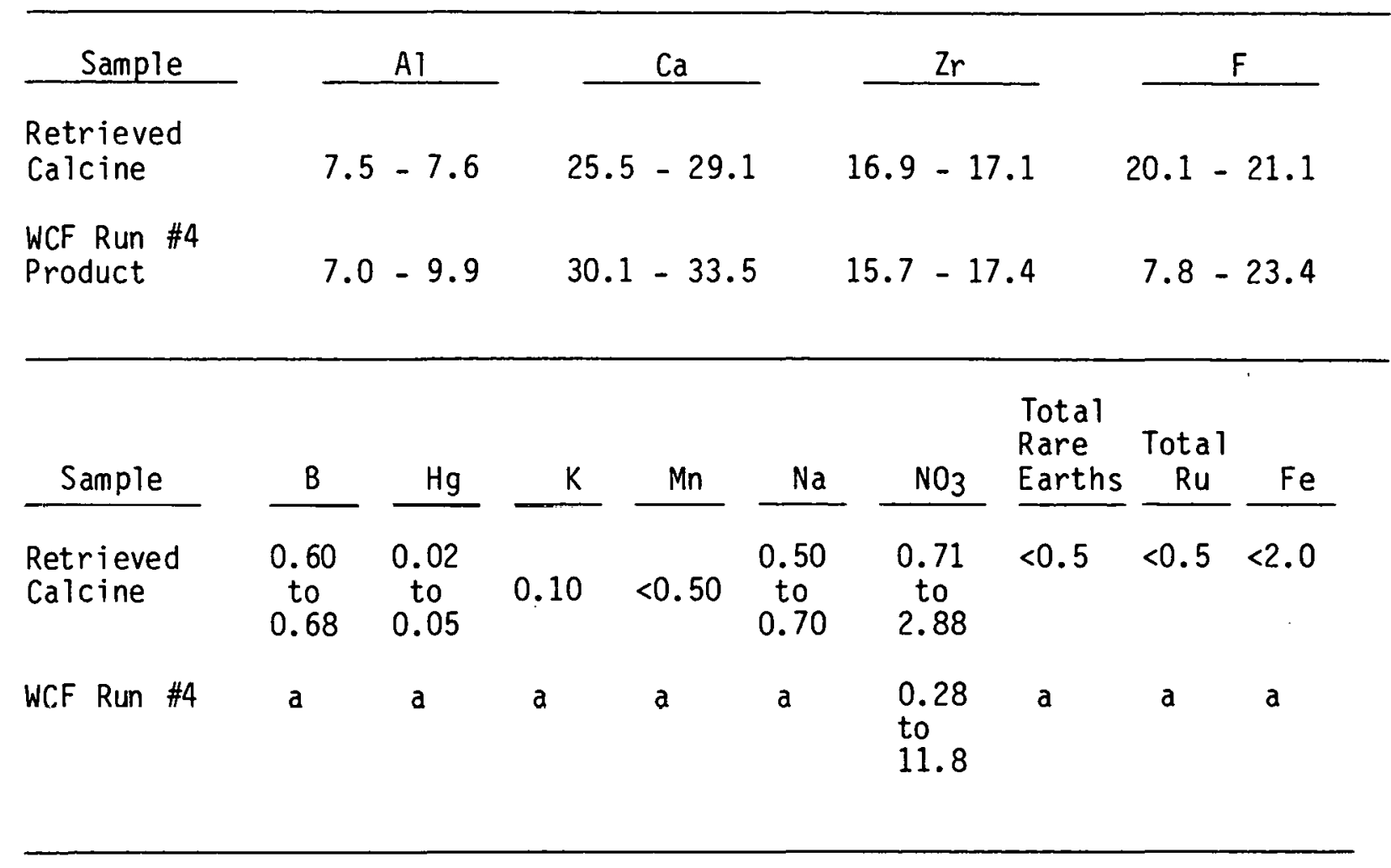

a Not determined 


\section{USE OF GLASS TO IMMOBILIZE ZIRCONIA CALCINE}

In the vitrification process zirconia calcine is mixed with frit 127 components (see Table III) in the ratio of 25-35 wt\% calcine to 6575 wt\% frit and heated at $1100^{\circ} \mathrm{C}$ for 3 hours. Lower ratios of combining calcine to frit components will aiso result in glass products of quality suitable for disposal in a repository6,7. After heating, a controlled cooldown or air quenching of the glass to ambient temperature can be performed, resulting in a product with little internal strain and of beneficial crystalline content. This process produces a high aluminosilicate content glass in which zirconia calcine matrix elements, including $A T, C a, F$ and $Z r$ and radionuclides contained in the calcine, are immobilized.

TAB̈LE III

COMPOSITION OF FORMULA 127 GLASS FRIT

Component

$\mathrm{SiO}_{2}$
$\mathrm{Na}_{2} \mathrm{O}$
$\mathrm{Li}_{2} \mathrm{O}$
$\mathrm{B}_{2} \mathrm{O}_{3}$
$\mathrm{CuO}$

Mole Percent

67.6

11.9

11.9

7.1

1.5
Weight Percent

70.3

12.8

6.2

8.5

2.1

The high alumino-silicate content of the Formula 127 glass, higher than other waste form glasses being developed, results in a product of high durability 8 . Two alkali metals, $\mathrm{Na}$ and $\mathrm{Li}$, are present in the frit to contribute to product durability and to result in a product of a wider viscosity working range. Copper is added in the frit to aid in uniform alumina dissolution and to decrease melt viscosity.

Before July 1981, a11 preparation and testing was performed on Formula 127 glass prepared with nonradioactive simulated calcine. Results of studies conducted on these glasses indicate that both radionuclides and calcine matrix elements should be adequately immobilized such that Formula 127 glass can be considered a final waste form for ICPP zirconia calcine. $6,7,8$ 
There are no obvious major physical differences between simulated and radioactive zirconia calcine. However, the radioactive calcine has been subjected to ionizing radiation and radiolytic heat for several years, whereas the simulated calcine has not. This exposure could result in physical changes, such as crystallization, to the calcine that could alter its behavior during vitrification, thus changing the product characteristics of the 127 glass.

There are no significant differences in major chemical components between radioactive and simulated zirconia calcine (see Tables II and IV). However, radioactive zirconia calcine contains radioisotopes of Cs, $\mathrm{Co}, \mathrm{Eu}$, and $\mathrm{Sr}$ and others, as well as the actinides $U, \mathrm{~Np}, \mathrm{Pu}$, and Am. Except for stable $\mathrm{Cs}$, Sr, and Eu which simulate the trivalent actinides, none of these species are present in simulated calcine. Thus, to demonstrate that these species are immobilized, 127 glass was prepared with retrieved radioactive zirconia calcine in July and August, 1981 and then sampled remotely for leaching and solid state characterization.

For the comparison of product properties and the factorial design experiment conducted as parts of this study, Formula 127 glass was prepared using $30-\mathrm{cm}$ experimental calciner run $\# 80$ product. The composition of this simulated calcine is given in Table IV.

The pilot scale melter was run for the first time in July and August 1981.9 The frit, simulated calcine, frit-to-calcine ratio and melting temperature used to prepare this glass was the same as used to prepare the laboratory scale glass. A core drilling of the pilot scale melter 127 glass product was sampled and characterized in this study to determine changes in leaching or solid state properties occurring through scale-up.

TABLE IV

COMPOSITION OF 30-cm CALCINER RUN \#80 PRODUCT

\begin{tabular}{lr} 
Element & wt\% \\
\cline { 2 - 2 } Ca & 27.50 \\
F & 23.00 \\
Zr & 15.30 \\
Al & 7.60 \\
B & 1.80 \\
Cs & 0.28 \\
Sr & 0.72
\end{tabular}


Calcined wastes from the reprocessing of nuclear fuels at the ICPP contain high levels of radionuclides. The principal radionuclide Curie content present in zirconia calcine retrieved from Bin Set 2 in 1978, and used to prepare 127 glass, are given in Table $V$.

TABLE $V$

PRINCIPAL RADIONUCLIDES PRESENT IN

RADIOACTIVE ZIRCONIA CAI.CINE RETRIEVED FROM BIN SET $2^{\mathrm{a}}$

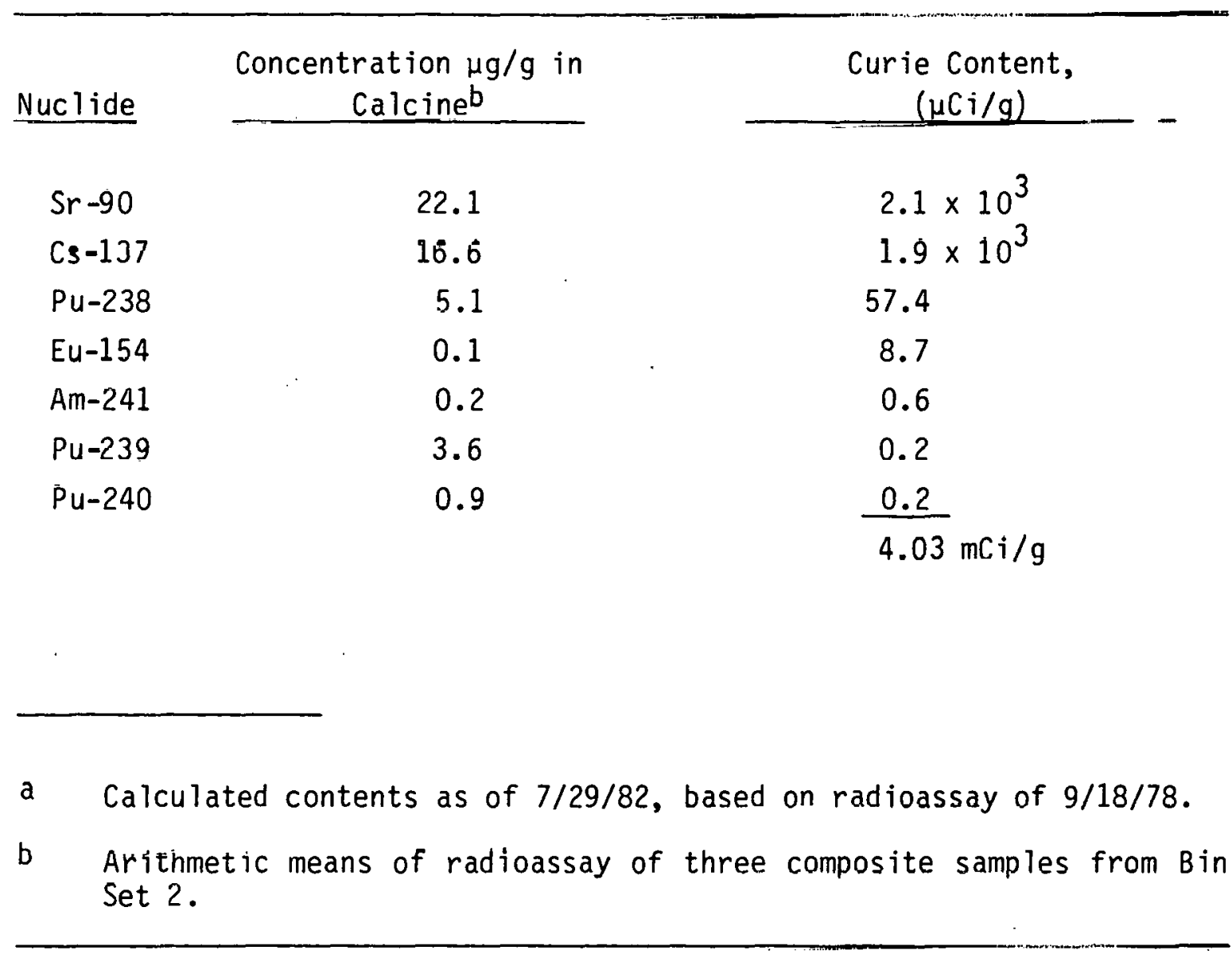

0 ther radionuclides, including Np-237 ( $\Omega 1 \mu \mathrm{g} / \mathrm{g}$ of calcine), present in the calcine, contribute negligible amounts to the Curie content given in Table $V$. 
Because of the radioactivity present in the calcine and because of the dispersibility, of the calcine, preparation of the glass (100 gram melts using 30 grams of calcine) was performed in the ARA I Hot cells. One of these cells was equipped with a Lindberg Model 5100 series furnace, an Ohaus Model 1050 balance and a Raytech Model A1-P10-S diamond wheel saw, each modified to perform remote glass melting and rough cutting operations. Glass was prepared in this cell by weighing calcine, combining it with externally tared frit in alumina crucibles and then fusing the crucible contents. After melting, and before rough cutting, molten 127 glass in crucibles was sampled by touching welding rods to the surface of the contents and pulling stringers away from the crucible. These stringers were cooled, placed in pieces of stainless steel tubing, and removed from the cell, to be cut up to provide milligram-size samples for chemical analysis and radioassay. After rough cutting, the glass specimens were transferred to another cell equipped with a South Bay Technology Model 650 low speed diamond wheel saw for fine cutting of samples. Photographs of these samples were taken on a millimeter square grid inside this cell for geometric surface area determination. Next the samples were transferred to a hot cell equipped with a Mettler HGT balance for constant weighing. A schematic diagram of the glass preparation steps performed remotely and directly is given in Figure 1. 


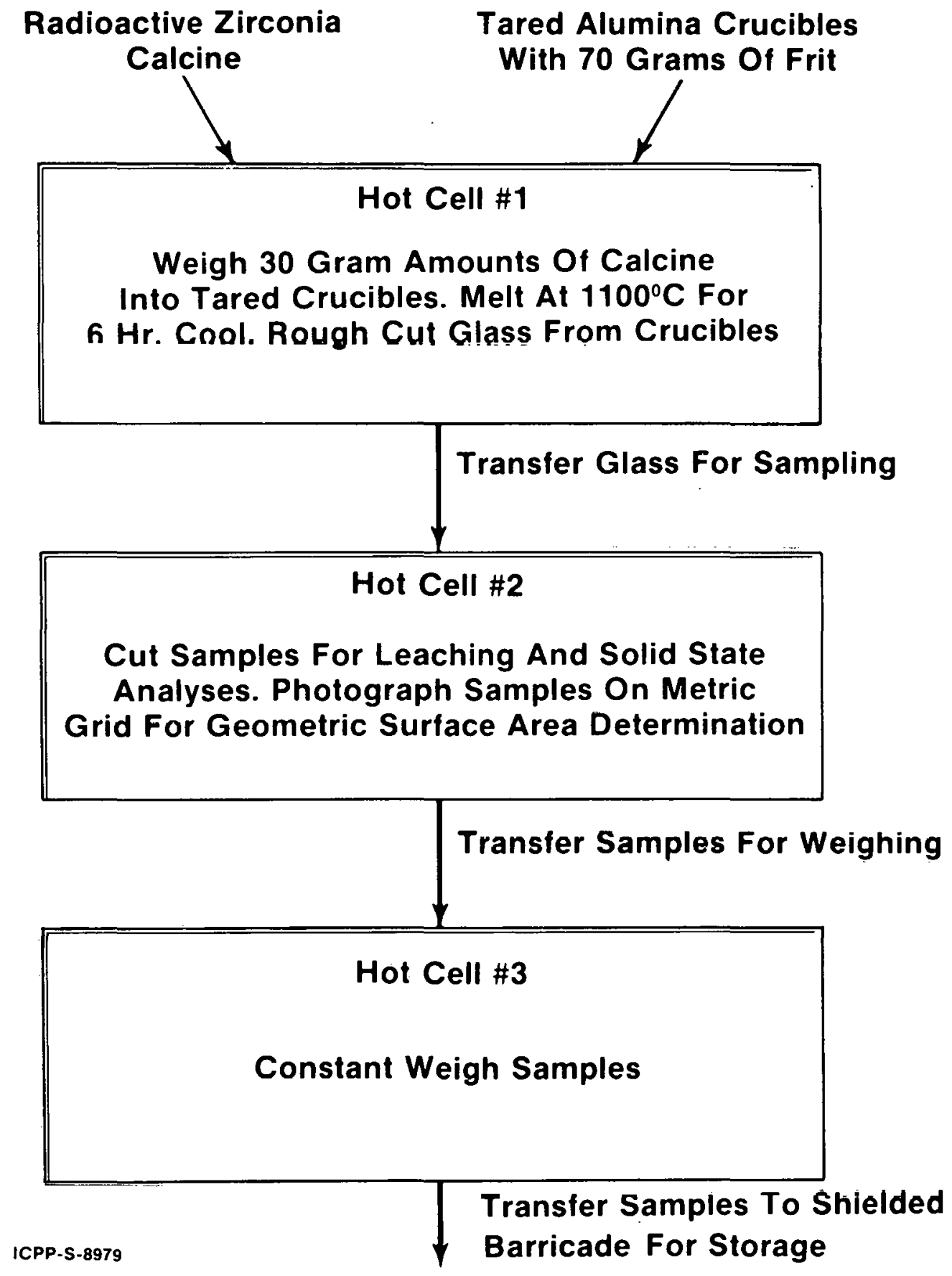

Figure 1. Hot Cel1 Activities for the Preparation and Sampling of Radioactive 127 Glass. 


\section{LEACHING PROPERTIES OF GLASS SAMPLES}

High levels of beta-gamma radiation are emitted from glass prepared with radioactive calcine. Thus, these samples were handled differently from samples prepared with nonradioactive simulated calcine. For example, radioactive samples must be cleaned of surface contamination introduced from the interior of the hot cells. Cleaning equipment, therefore, was placed in a hood to contain this dispersible radioactivity. Nonradioactive samples were cleaned separately on a laboratory bench. Cleaning radioactive and nonradioactive samples simultaneously in the hood was not performed in order to lower radiation doses to personnel and to reduce the amount of contaminated equipment generated.

\section{A. Specimen Cleaning Before Leaching}

Cleaning procedures used on nonradioactive glass samples were those suggested in the application of the MCC-1 static leach test. 10 Radioactive specimens were cleaned in the same manner except that more cleaning periods were required to reduce their dispersible surface contamination to background levels.

\section{B. Soxhlet Leach Test}

The Soxhlet test is meant to simulate the response of candidate waste form materials when submerged in a flowing aqueous system.11 In this study, the tests were conducted on duplicate materials for 72 hours. Standard conditions included conducting the test at $95^{\circ} \mathrm{C}$ with $150 \mathrm{~mL}$ of distilled water as the leachant. At the end of the test leached specimens were washed with distilled water, dried, and weighed to the nearest constant $0.2 \mathrm{mg}$ to determine mass loss through leaching. Leachants from the tests were acidified with concentrated $\mathrm{HNO}_{3}$ to prevent element plateout onto container walls during storage, diluted to $250 \mathrm{~mL}$ and transferred to pre-conditioned polyethylene bottles for storage before analysis.

\section{MCC-1 Low Temperature Static Leach Test}

This static leach test is used to simulate the response of candidate waste form materials when submerged in non-flowing aqueous systems. 10 In this study, the test was conducted at $90^{\circ} \mathrm{C}$ using only deionized distilled water leachant because of analytical cost and time requirements. Leaching containers were preconditioned as recommended in the MCC -1 static leach test procedure. Single samples were about $5 \times 10^{-4} \mu 2$ surface area samples of each material tested were leached in about $50 \mathrm{~mL}$ deionized distilled water for 3,7 , and 14 days, while triplicate samples of each material were leached in the same volume for 28 days. Duplicate deionized distilled water samples to be used as solution blanks were also treated for 28 days under the same conditions as the leached sample materials. At the end of the test the leached samples were rinsed in distilled water, dried, and weighed to the nearest constant $0.1 \mathrm{mg}$ to determine mass loss through leaching (see Appendix A). Leachates from the test were acidified with concentrated $\mathrm{HNO}_{3}$ to prevent elemental plateout onto the container during storage prior to chemical analys is. 


\section{MCC -2 High Temperature Static Leach Test}

This test is performed in the same manner as the MCC-1 test except that the leaching vials are contained in acid digestion bombs.10 In this study, the tests were conducted at $150^{\circ} \mathrm{C}$ using only distilled deionized water because of analytical costs and time requirements.

\section{E. Factorial Design Experiment}

A four-level experiment based on the 28-day MCC-1 static leach test was performed to determine the total mass loss rate response to changes in four important test conditions. 12 The four conditions varied in the test were leaching temperature, leachant solution, sample surface area-to-leachant volume and use of radioactive or simulated calcine in glass preparation. The design matrix illustrating test conditions and variables is given in Table XII.

F. Chemical Analysis and Radioassay of Leachates and Dissolved Glasses

Chemical analysis of all leachates generated and glasses dissolved was performed by inductively coupled plasma enlssiun spectroseopy (ICP) and flame atomic emission spectroscopy (AES). Table VI presents the elemental analyses requested on leachates and dissolved glasses.

\section{TABLE VI}

ELEMENTS DETERMINED IN GLASSES AND. LEACHATES

\begin{tabular}{lcc}
\hline Method & Glass & $\frac{\text { Leachates }}{\mathrm{C}}$ \\
\cline { 2 - 2 } & $\mathrm{Cr}$ & $\mathrm{Ca}$ \\
$\mathrm{AES}$ & $\mathrm{Cs}$ & $\mathrm{Sr}$ \\
\hline
\end{tabular}

For chemical analysis, weighed samples of glasses were dissolved in $\mathrm{HF}$, then heated to dryness. The resulting residue was dissolved in $1: 1$ conc. $\mathrm{HNO}_{3}$ :conc. $\mathrm{HCL}$ and diluted to a known volume for analysis. Determination of these elements was performed on radioactive and nonradioactive glasses because the radioactive and stmulaled calcines with which they were prepared were not of the same composition. Solutions of the dissolved radioactive glass, and its leachates, contain radioactive and nonradioactive fission products, as well as natural process residues of $\mathrm{Cs}$ and $\mathrm{Sr}$, whereas solutions of nonradioactive glass and its leachates contain these elements only as natural components of the simulated calcine. Calcium, an important matrix element of the actual and simulated 
calcines, was determined in solution to establish its concentration in glasses and its leachability. Thus a comparison of leaching properties of the radioactive and nonradioactive glasses could be made based on the fraction of total contained elements or nuclides leached.

Radioassay to determine gamma-emitting radionuclides, $\mathrm{Sr}-90$ and transuranics in the dissolved glass prepared with radioactive calcine and leach solutions of the glass was also performed. Figure 2 illustrates a 2000 second gamma scan of a $1-\mathrm{mL}$ aliquot from the radioactive glass dissolved and diluted to $100 \mathrm{~mL}$. Gamma scans and alpha pulse height analy$\mathrm{s}$ is were performed directly on aliquots, while Sr-90 and Am-241 were determined by separation from solution aliquots and subsequent beta counting.

Analyses of glasses used in this study are given in Table VII. Cesium-137 and total Sr content of the radioactive glass was used for comparison of normalized $C s$ and $S r$ losses from glasses prepared with simulated calcine. Americium-241 and $\mathrm{Pu}-238$ were also determined in the radioactive glass. However, Am-241 was not present in amounts large enough for accurate analysis in any of the leachates generated in this study.

TABLE VII

COMPONENTS OF 127 GLASSES SUBJECTED

TO LEACH AND SOLID STATE CHARACTERIZATIONa

A. Glass Prepared with Actual Zirconia Calcine
$\mathrm{Sr}$
$\mathrm{Ca}$
Cs 137
$\mathrm{Sr}^{90}$
$\mathrm{Pu}^{238}$
$A m 241$
$5.98 \times 10^{-6}$
$9.80 \times 10^{-2}$
$6.71 \times 10^{-6}$
$3.72 \times 10^{-6}$
$2.80 \times 10^{-7} \quad 1.29 \times 10^{-9}$

B. Glass Prepared with Simulated Zirconia Calcine in Laboratory

Cs

Sr

$\mathrm{Ca}$

$5.07 \times 10^{-5}$

$1.13 \times 10^{-4}$

$1.20 \times 10^{-1}$

C. Glass Prepared in Pilot Melter with Simulated Zirconia Calcine

CS

$1.3 \times 10^{-4}$
$\mathrm{Sr}$

$1.4 \times 10^{-4}$
$\mathrm{Ca}$

$4.8 \times 10^{-2}$

a Results are given in grams of element or nuclide per gram of glass and are corrected for blank concentrations. 


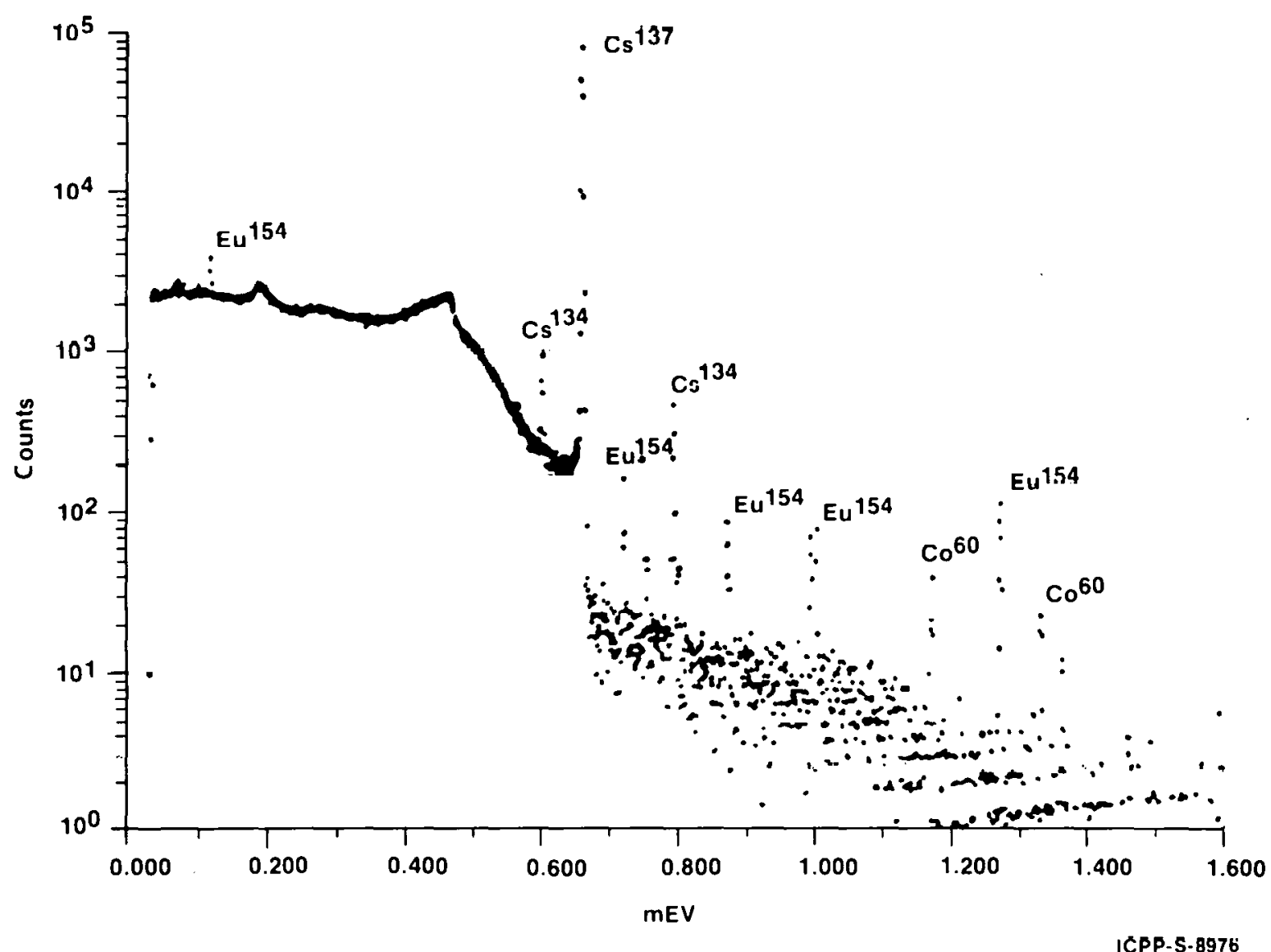

Figure 2. Two Thousand Second Gamma Scan of 1-mL Aliquot from 100-mL Dissolution of Radioactive 127 Glass Sample 


\section{G. Soxhlet Leach Test Results}

Table VIII presents mass loss rates and normalized elemental losses obtained from analyses of leachates generated by applying the Soxhlet leach test samples of 127 glass prepared with simulated or radioactive zirconia calcine. Plutonium-238 was not present in sufficient quantities in the leachates of radioactive glass to result in an accurate determinations. Cesium was not determined in glass prepared with radioactive calcine. Through application of the Soxhlet leach test, mass losses from the 127 glass prepared with radioactive calcine, in the laboratory with simulated calcine, and in the pilot scale melter with simulated calcine, were similar, indicating little significant difference from each glass. Likewise, $\mathrm{Ca}$ and $\mathrm{Sr}$ loss rates obtained are similar for all three glasses. Cesium loss rates from the glasses prepared with simulated calcine are similar.

TABLE VIII

TOTAL MASS LOSS RATES AND

NORMAL IZED ELEMENTAL LOSS RATES FROM 127 GLASS SUBJECTED TO SOXHLET LEACH TESTa

\begin{tabular}{|c|c|c|c|c|}
\hline \multirow{2}{*}{$\begin{array}{l}\text { Calcine Type Used } \\
\text { in Preparation } \\
\end{array}$} & \multicolumn{4}{|c|}{ Leach rate in $\mathrm{g} / \mathrm{m}^{2}$. day } \\
\hline & $\begin{array}{c}\text { Mass } \\
\text { Loss Rate } \\
\end{array}$ & Ca Loss & Sr Loss & Cs Loss \\
\hline $\begin{array}{l}\text { Radioactive Zirconia } \\
\text { Calcine }\end{array}$ & 1.7 & 4.9 & 82.0 & b \\
\hline $\begin{array}{l}\text { Simulated Zirconia } \\
\text { Calcine in the } \\
\text { Laboratory }\end{array}$ & 3.1 & 9.3 & 62.5 & 4.3 \\
\hline $\begin{array}{l}\text { Simulated Zirconia } \\
\text { Calcine in the } \\
\text { Pilot Scale Melter }\end{array}$ & 3.8 & 14.4 & 29.3 & 9.0 \\
\hline $\begin{array}{l}\text { a } \\
\text { best run at } 95^{\circ} \mathrm{C} \\
\text { not determined b }\end{array}$ & $\begin{array}{l}72 \text { hours. } \\
\text { ise of insu }\end{array}$ & ient sam & & \\
\hline
\end{tabular}

H. MCC-1 and MCC-2 Static Leach Test Results

Table IX presents normalized elemental and nuclide losses obtained from the analyses of leachates generated by applying MCC-1 and MCC -2 to samples of 127 glass prepared with radioactive calcine. Likewise, Table $X$ presents the normalized elemental losses obtained for the application of MCC-1 and MCC-2 on 127 glass prepared with simulated calcine in the laboratory, and Table XI presents the same results from applying MCC-1 and MCC-2 to 127 glass prepared in the pilot scale melter with simulated calcine. Total mass losses from the glass samples subjected to these tests are also presented in each table. The calculation methods for obtaining these results are illustrated in Appendix A. 
TOTAL MASS LOSS AND NORMALIZED ELEMENTAL LOSSES FROM GLASS PREPARED WITH ACTUAL RADIOACTIVE ZIRCONIA CALCINE AND SUBJECTED TO STATIC LEACH TESTS, $\mathrm{g} / \mathrm{m}^{2}$

\begin{tabular}{|c|c|c|c|c|c|}
\hline \multirow[b]{2}{*}{$\begin{array}{c}\text { Days } \\
\text { Leached }\end{array}$} & \multirow[b]{2}{*}{$\begin{array}{c}\text { Total Mass } \\
\text { Loss } \\
\end{array}$} & \multicolumn{2}{|r|}{$M C C-1^{a}$} & \multirow[b]{2}{*}{$\begin{array}{c}\text { Total } \\
\text { Sr Loss } \\
\end{array}$} & \multirow[b]{2}{*}{$\begin{array}{r}\text { Pu238 } \\
\text { Loss } \\
\end{array}$} \\
\hline & & $\begin{array}{l}\text { Tota } 1 \\
\text { Ca Loss } \\
\end{array}$ & $\begin{array}{l}\text { Cs137 } \\
\text { Loss } \\
\end{array}$ & & \\
\hline 3 & 4.42 & 5.09 & 1.34 & 1.55 & 0.03 \\
\hline 7 & 3.78 & 2.83 & 4.41 & 3.87 & 0.01 \\
\hline 14 & 5.32 & 4.36 & 5.70 & 4.64 & 0.01 \\
\hline $28^{b}$ & 6.35 & 3.84 & 6.74 & 4.63 & 0.01 \\
\hline \multicolumn{6}{|c|}{$M C C=25$} \\
\hline 3 & 23.91 & 2.33 & 25.85 & 25.75 & 0.07 \\
\hline 7 & 20.09 & 1.91 & 28.06 & 22.51 & 0.01 \\
\hline 14 & 27.16 & 2.25 & 31.49 & 24.08 & 0.01 \\
\hline $28^{b}$ & 29.40 & 2.50 & 38.09 & 26.46 & 0.01 \\
\hline
\end{tabular}

a Tests performed at $90^{\circ} \mathrm{C}$ with deionized distilled water coolant leachant

b Average of triplicate analyses

C Tests performed at $150^{\circ} \mathrm{C}$ with deionized distilled water leachant. 
TABLE $X$

TOTAL MASS LOSS AND NORMALIZED ELEMENTAL LOSSES FROM GLASS PREPARED WITH SIMULATED ZIRCONIA CALCINE IN THE LABORATORY AND SUBJECTED TO STATIC LEACH TESTS, $\mathrm{g} / \mathrm{m}^{2}$

\begin{tabular}{|c|c|c|c|c|}
\hline \multicolumn{5}{|c|}{$M C C-1^{a}$} \\
\hline $\begin{array}{c}\text { Days } \\
\text { Leached }\end{array}$ & $\begin{array}{l}\text { Total Mass } \\
\text { Loss } \\
\end{array}$ & $\begin{array}{c}\text { Total } \\
\text { Ca Loss } \\
\end{array}$ & $\begin{array}{c}\text { Total } \\
\text { Cs Loss } \\
\end{array}$ & $\begin{array}{c}\text { Total } \\
\text { Sr Loss } \\
\end{array}$ \\
\hline 3 & 1.59 & 1.31 & 2.20 & 0.15 \\
\hline 7 & 3.10 & 2.24 & 4.25 & 0.34 \\
\hline 14 & 4.05 & 2.50 & 4.38 & 0.39 \\
\hline $28^{b}$ & 3.53 & 2.71 & 9.28 & 0.43 \\
\hline \multicolumn{5}{|c|}{$M C C-2^{C}$} \\
\hline 3 & 8.01 & 3.75 & 18.89 & 0.60 \\
\hline 7 & 8.61 & 3.03 & 20.22 & 0.56 \\
\hline 14 & 9.42 & 3.25 & 22.22 & 0.56 \\
\hline $28^{b}$ & 9.33 & 3.24 & 21.41 & 0.53 \\
\hline
\end{tabular}

a Tests performed at $90^{\circ} \mathrm{C}$ with deionized distilled water leachant

b Average of triplicate analyses

C Tests performed at $150^{\circ} \mathrm{C}$ with deionized distilled water leachant. 
TOTAL MASS LOSS AND NORMALIZED ELEMENTAL LOSSES FROM GLASS

PREPARED WITH SIMULATED ZIRCONIA CALCINE IN THE PILOT SCALE MELTER AND SUBJECTED TO STATIC LEACH TESTS, $\mathrm{g} / \mathrm{m}^{2}$

\begin{tabular}{|c|c|c|c|c|}
\hline \multirow[b]{2}{*}{$\begin{array}{c}\text { Days } \\
\text { Leached }\end{array}$} & \multicolumn{3}{|c|}{$M C C-1^{a}$} & \multirow[b]{2}{*}{$\begin{array}{r}\text { Total } \\
\text { Sr Loss } \\
\end{array}$} \\
\hline & $\begin{array}{c}\text { Total Mass } \\
\text { Loss } \\
\end{array}$ & $\begin{array}{c}\text { Total } \\
\text { Ca Loss } \\
\end{array}$ & $\begin{array}{c}\text { Total } \\
\text { Cs Loss } \\
\end{array}$ & \\
\hline 3 & 2.22 & 13.60 & 1.54 & 3.59 \\
\hline 7 & 3.50 & 13.21 & 4.57 & 3.53 \\
\hline 14 & 4.48 & 10.95 & 5.87 & 8.38 \\
\hline $28^{b}$ & 6.18 & 14.43 & 5.92 & 9.20 \\
\hline & & $M C C=2^{C}$ & & \\
\hline 3 & 8.91 & 5.47 & 23.20 & 6.26 \\
\hline 7 & 9.87 & 5.63 & 21.34 & 5.71 \\
\hline 14 & 10.68 & 4.87 & 34.42 & 4.39 \\
\hline $28^{b}$ & 11.03 & 3.51 & 16.09 & 4.49 \\
\hline
\end{tabular}

a Tests performed at $90^{\circ} \mathrm{C}$ with deionized distilled water leachant

b Average of triplicate analyses

c Tests performed at $150^{\circ} \mathrm{C}$ with deionized distilled water leachant. 
The elemental and total mass losses given in Tables IX through XI can be converted to normalized average leach rates (See Appendix A) which are displayed in Figures 3 through 7.

With respect to total mass loss rates (Figure 3 ) the three glasses respond to each test in a very similar manner. The slightly higher mass loss rates obtained from the glasses subjected to MCC -2, than from those subjected to MCC-1, are not significant. Normalized Cs loss rates (Figure 4) from the three glasses (through application of the tests) are very similar to the total mass loss rates, suggesting Cs leaching is congruent to the destruction of the original glass structure. Strontium, like Cs, is a minor constituent in the glasses, particularly where present as a radionuclide in the glass prepared with radioactive calcine. However, normalized $\mathrm{Sr}$ leach rates from the glasses (Figure 5) do not conform to those of total mass and Cs loss, indicating the influence of other mechanisms in addition

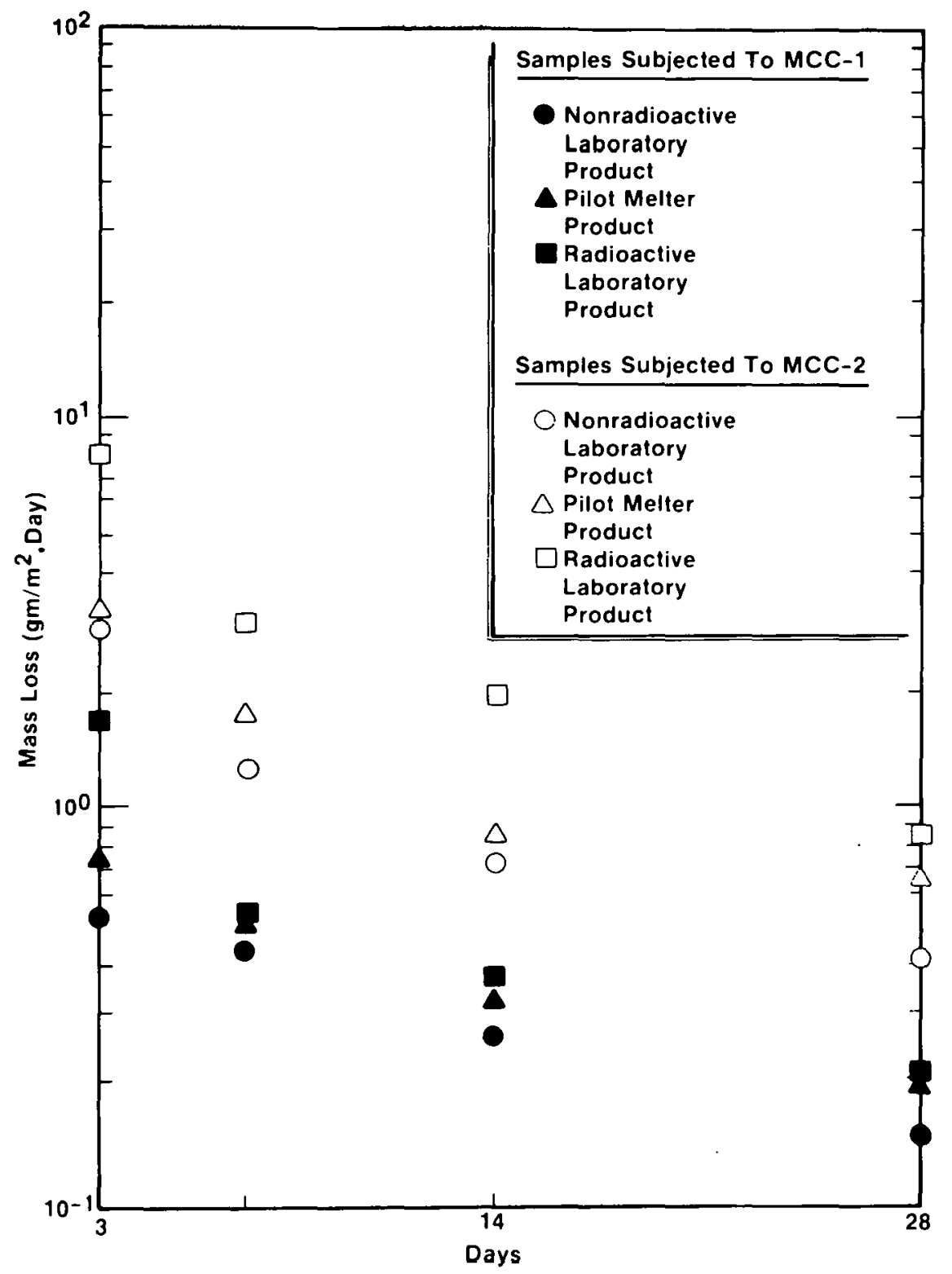

Figure 3. Total Mass Loss Rates from 127 Glass Samples Subjected to MCC-1 and MCC-2 for $3,7,14$, and 28 Days 


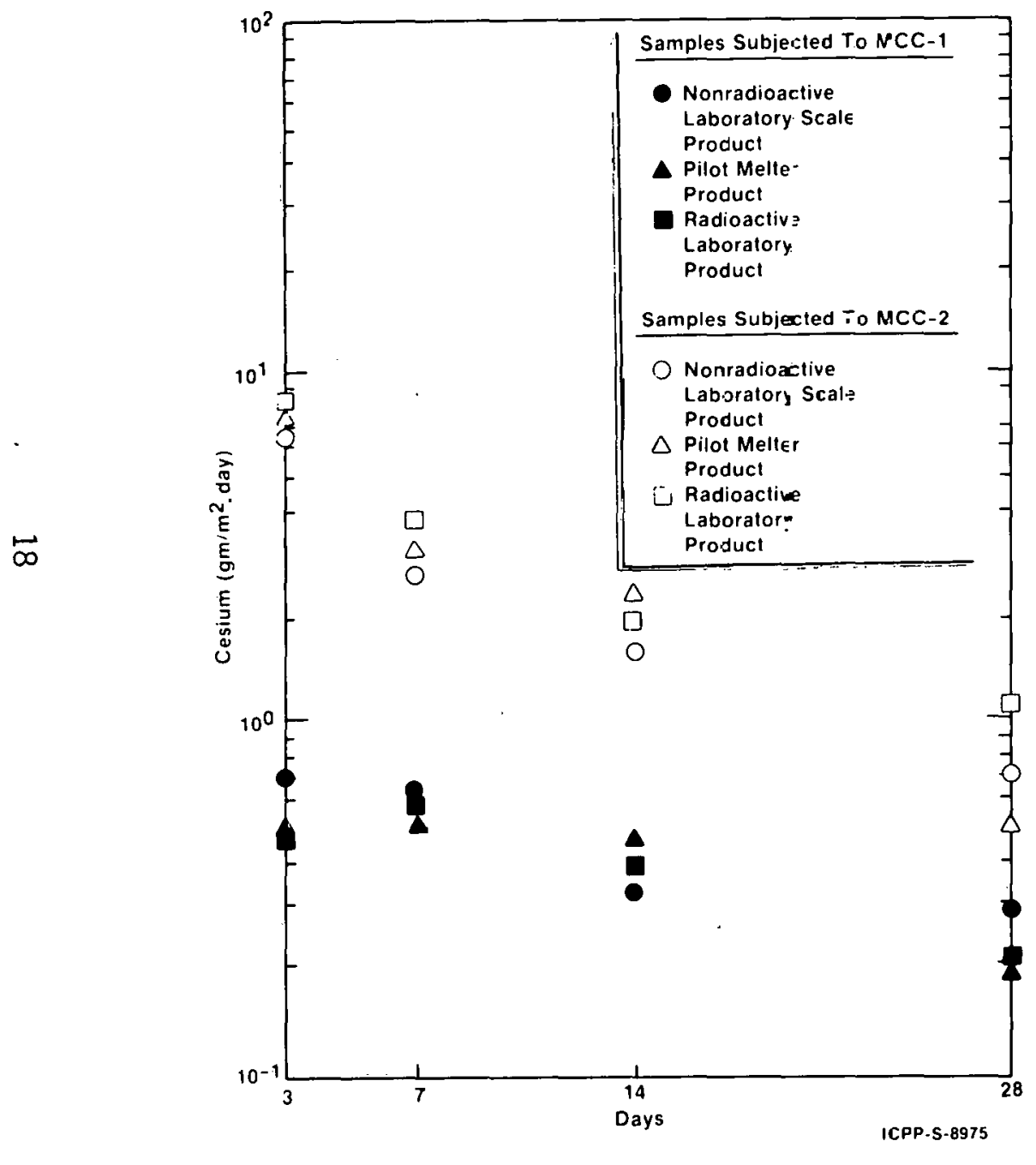

Figure 4. Cessium Loss Rates Fron 127 alass Samples Sutjecited to $M C=-1$ and $M C C-2$ for $3,7,14$, and 28 Days.

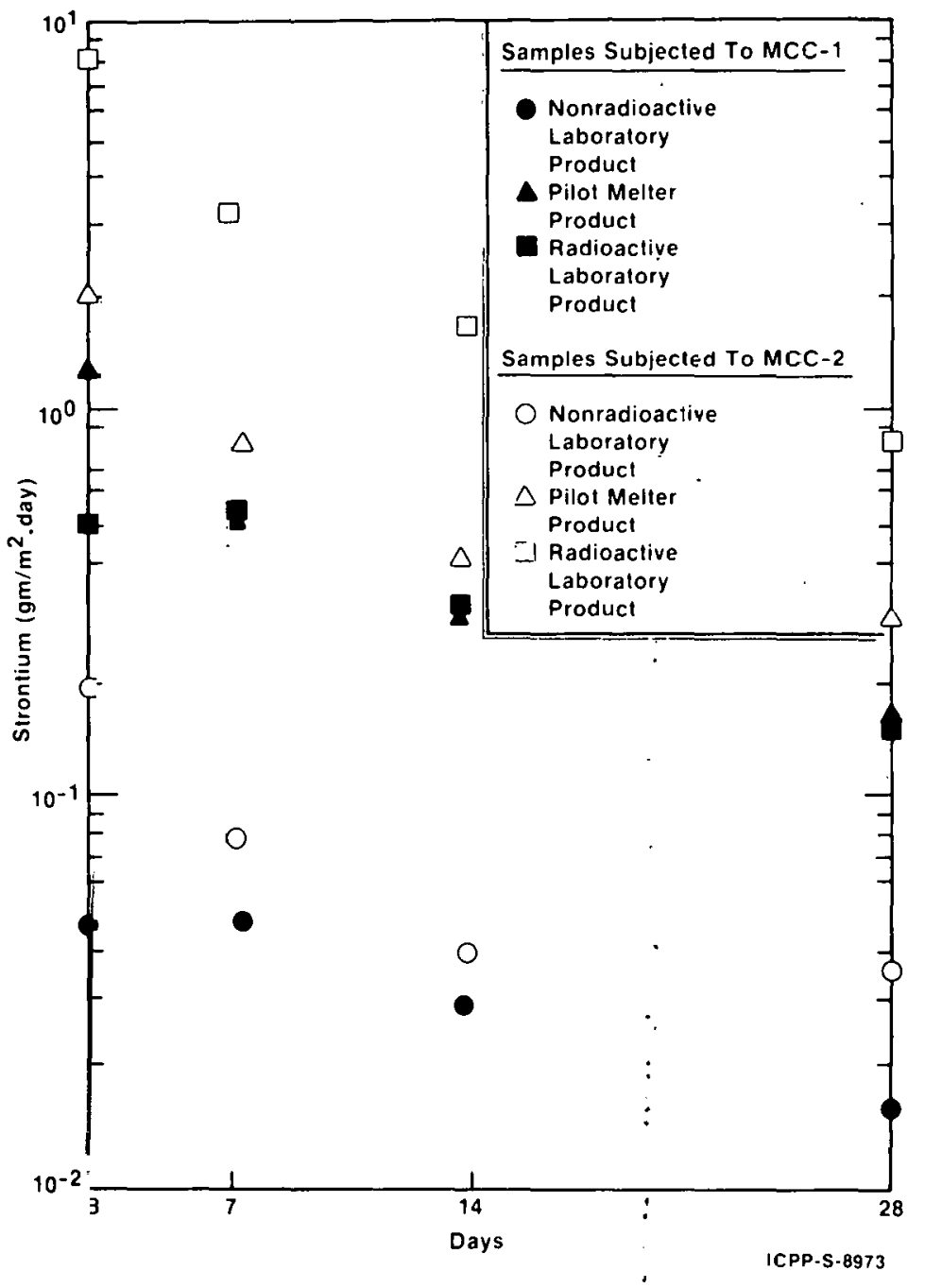

Figure 5. Strontium Loss Rates from 127 Glass Samples Subjected to MCC-1 and MCC-2 for $3,7,14$, and 23 Days. 


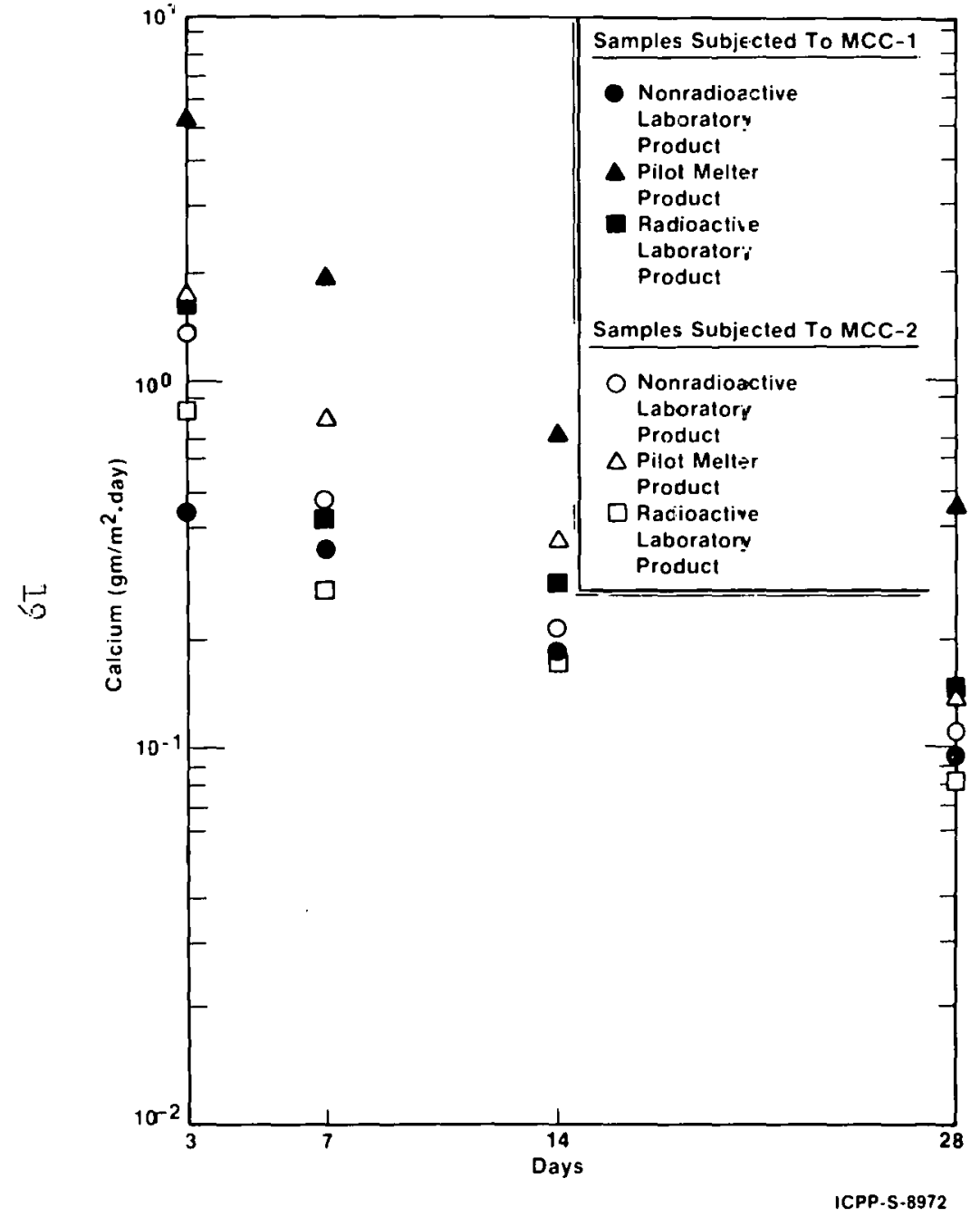

Figure 6. Calcium Loss Rates from 127 Glass Samples Subjected to MCC- 1 and MCC-2 for $3,7,14$, and 28 Days.

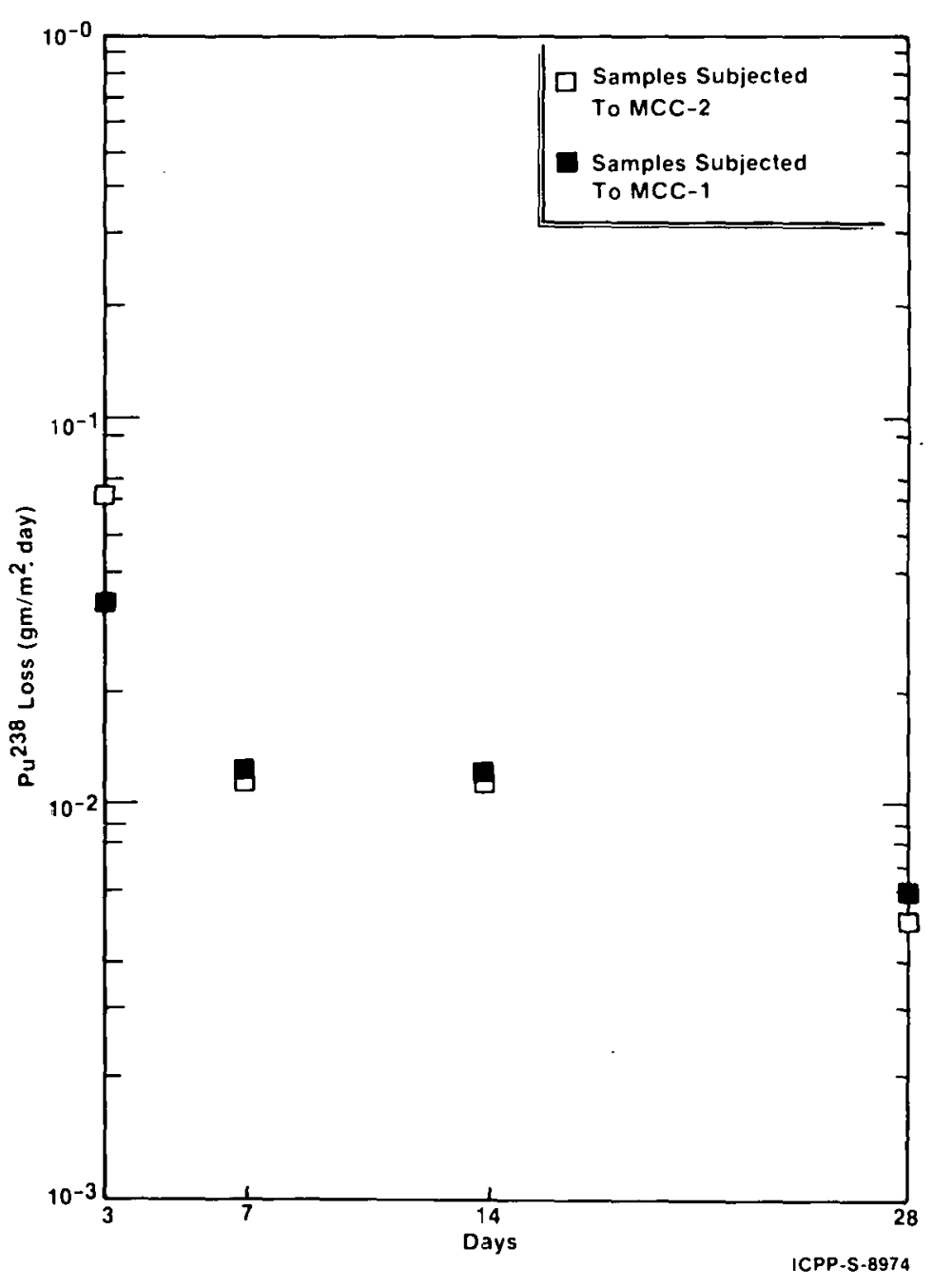

Figure 7. Plutonium Loss Rates from Radioactive 127 Glass Samples Subjected to MCC-1 and MCC-2 for 3, 7, 14, and 28 Days. 
to glass dissolution. The influence of other mechanisms on $\mathrm{Sr}$ leach rate from the glass is also suggested by the results of these tests, which indicate that $\mathrm{Sr}$ leaches at a rate about an order of magnitude less than total mass loss. In fact, Sr appears to leach from the laboratory glass prepared with simulated calcine at a rate nearly two orders of magnitude less than total mass loss.

Calcium is a major constituent of the simulated and radioactive calcines and thus is an important constituent of the glasses to which they are converted. As with $\mathrm{Sr}$, $\mathrm{Ca}$ leaches at a rate (Figure 6) about an order of magnitude less than that of total mass loss indicating effects of mechanisms other than glass dissolution. The results from applying both tests also indicate that $\mathrm{Ca}$ leach rates from all three glasses are similar to each other and have no significant difference between $90^{\circ}$ and $150^{\circ} \mathrm{C}$. Plutonium-238 leach rates from glass prepared with radioactive calcine and subjected to $M C C-1$ and $M C C-2$ are given in Figure 7. The leach rates from applying both tests are similar and are about two orders of magnitude less than total mass loss of the glass, also indicating a complex leaching mechanism. Trace amounts $(<0.1 \mathrm{ng})$ of plutonium-239, -240 were detected in the MCC-1 and MCC-2 leachates. However, these nuclides were present in amounts too small for accurate determination. No other actinides could be detected in these leachates.

\section{Factorial Design Experiment Results}

Sixteen 28-day MCC-1 leach tests were performed on samples of 127 glass using the systematic combination of variables shown in Table XII. The total mass loss rate from the glass sample leached in each test was used as the response on which to perform the data analysis of the experiment. The statistical analysis consisting of the Yates algorithm and analysis of variance (See Appendix B) was performed on the total mass loss rate results obtained by applying the factorial design experiment. The results of these analyses indicate that only a variation in leaching temperature between $40^{\circ}$ and $90^{\circ} \mathrm{C}$ has a significant effect at the $95 \%$ confidence level on the total mass loss rate from the samples. Leachant type (brine or water), surface area to volume $\left(1: 10 \mathrm{~m}^{-1}\right)$ and the type of zirconia calcine used in preparing the glass (simulated or radioactive calcine) or any combination of change in these variables do not have significant effects on the total mass loss rate from the glass samples as determined within the limits of this test. 
TABLE XII

MATRIX OF FACTORIAL DESIGN EXPERIMENT

BASED ON MCC-1 STATIC LEACH TEST

\begin{tabular}{|c|c|c|c|c|c|}
\hline & $\begin{array}{c}X 1 \\
\text { Leach Test } \\
\text { Temp., }{ }^{\circ} \mathrm{C}\end{array}$ & $\begin{array}{c}\text { X2 } \\
\text { Leachant } \\
\text { Type }\end{array}$ & $\begin{array}{c}\text { X3 } \\
\text { Surface Area } \\
\text { To Volume Ratio }\end{array}$ & $\begin{array}{c}\text { X4 } \\
\text { Calcine } \\
\text { Vitrified }\end{array}$ & $\begin{array}{l}\text { Total Mass } \\
\text { Loss Response } \\
\text { g/m2 • Day }\end{array}$ \\
\hline+ & 90 & MCC-1 Brine a & 10 & Actual $^{b}$ & \\
\hline - & .40 & Dist. Deionized $\mathrm{H}_{2} \mathrm{O}$ & 1 & Simulated $^{c}$ & \\
\hline
\end{tabular}

Test No.

\begin{tabular}{|c|c|c|c|c|c|}
\hline 1 & - & - & - & - & 0.04 \\
\hline 2 & + & - & - & - & 0.64 \\
\hline 3 & - & + & - & - & 0.08 \\
\hline 4 & + & + & - & - & 0.34 \\
\hline 5 & - & - & + & - & 0.06 \\
\hline 6 & + & - & + & - & 0.16 \\
\hline 7 & - & + & + & - & 0.06 \\
\hline 8 & + & + & + & - & 0.11 \\
\hline 9 & - & - & - & + & 0.08 \\
\hline 10 & + & - & - & + & 1.45 \\
\hline 11 & - & + & - & + & 0.06 \\
\hline 12 & + & + & - & + & 0.21 \\
\hline 13 & - & - & + & + & 0.06 \\
\hline 14 & + & - & + & + & 0.13 \\
\hline 15 & - & + & + & + & 0.04 \\
\hline 16 & + & + & + & + & 0.17 \\
\hline
\end{tabular}

a. Brine composition; $48.2 \mathrm{~g} \mathrm{KCl}, 90.0 \mathrm{~g} \mathrm{NaCl}$ and $116.0 \mathrm{~g} \mathrm{MgCl} 2$ per liter $\mathrm{H}_{2} \mathrm{O}$.

b. See Tables II and IV for composition.

c. See tables III and IV for composition 


\section{SOLID STATE PROPERTIES OF GLASS PREPARED WITH \\ RADIOACTIVE AND SIMULATED ZIRCONIA CALCINE}

\section{A. Surface Analysis by ESCA}

1. Experimental

Glass samples were analyzed at room temperature by ESCA. (Electron Spectroscopy for Chemical Analysis), in combination with ion-milling, using a Physical Electronics 549 system. The X-ray source anode used was magnesium ( $\mathrm{Mg} \mathrm{K \alpha}=1253.6 \mathrm{eV})$. Samples were rinsed in acetone prior to analysis. Alkali migration during analysis was not experienced at room temperature for Formula 127 glass prepared with either simulated or radioactive zirconia calcine.

Ion-milling was performed using Ar ions to etch the glass surface. The sample surface was etched until a given depth was reached and the freshly exposed surface was analyzed by ESCA. This procedure was repeated to obtain elemental depth profiles of atomic concentration. The Ar ion milling etch rate was calibrated against a standard Ta20 5 film nf known thickness. The etch rate of $\mathrm{SiO}_{2}$ is approximately 1.2 times slower than that of $\mathrm{Ta}_{2} \mathrm{O}_{5}$.

2. Bulk Analysis

Stringers of 127 glass prepared with simulated zirconia calcine in both the laboratory and the pilnt. srale meltegr were fractured under vacuum ( $1 \times 10^{-10}$ Torr) in the ESCA analys is chamber. The stringers were fractured under vacuum to provide a surface for analysis that had not been contaminated by atmospheric exposure. The fractured surfaces of both samples were analyzed by ESCA to determine their bulk compositions (See Fig. 8) and to determine the elemental sensitivity factors characteristic of the glass matrix. The relative atomic percent of the elements detected is listed in Table XIII for both laboratory and pilot scale melter glasses. Relative elemental sensitivity factors employed in the calculations were empirically determined by normalization of the ESCA peak areas to the known bulk concentration of the laboratory glass. The data demonstrate that the bulk elemental composition of the laboratory glass is the same as that of the pilot scale melter glass. Neither Cs nor $\mathrm{Fe}$ were detectable in either bulk glass due to concentrations which were less than 0.1 atomic \% (detection limit).

3. Unleached Glass

Unleached, diamond-cut surfaces of Formula 127 glass prepared with simulated zirconia calcine in the pilot scale melter and prepared with radioactive zirconia calcine in the laboratory 


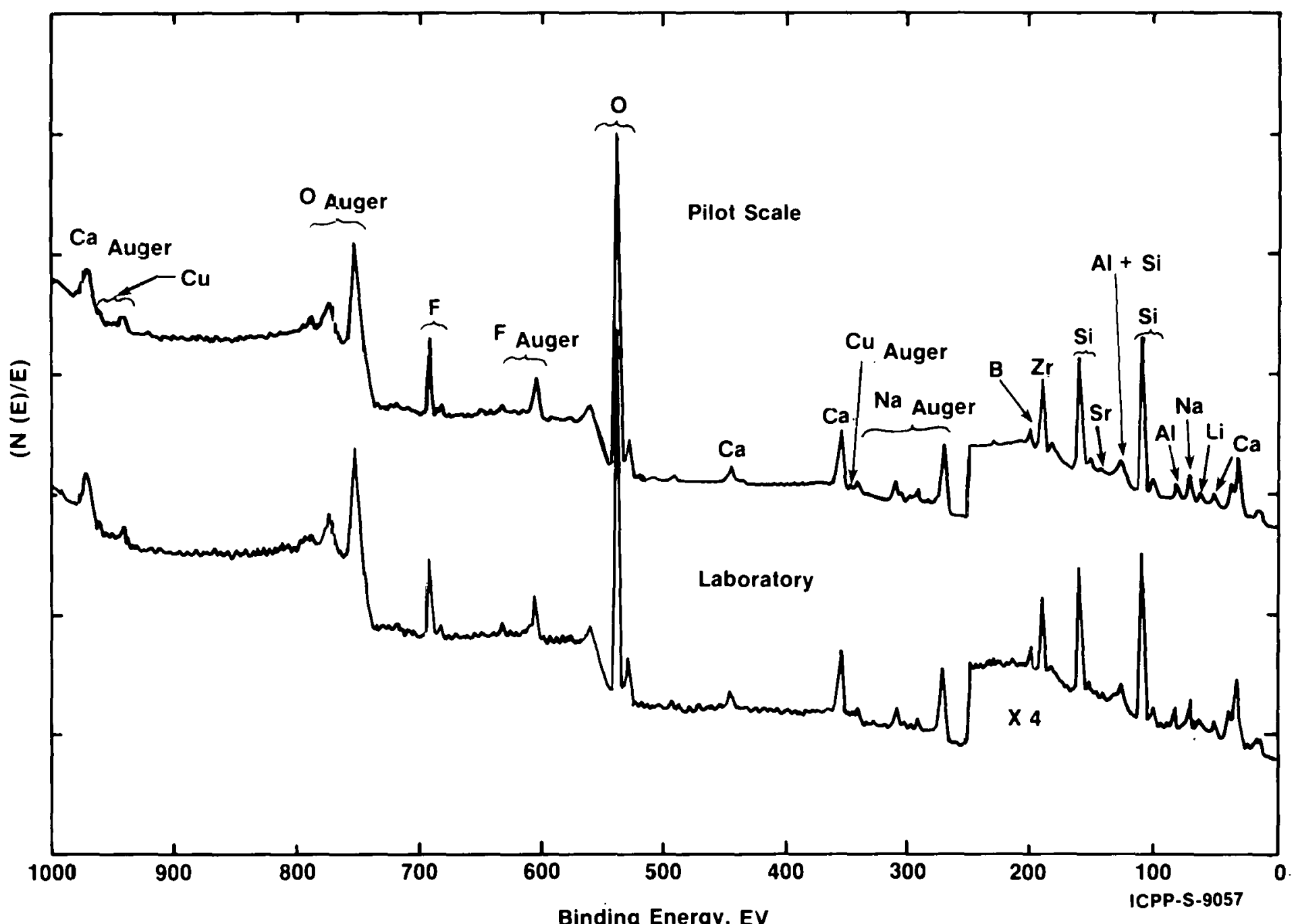

Figure 8. ESCA Spectra of Vacuum Fractured 127 Glass Prepared with Simulated Zirconia Calcine in the Pilot Scale Melter and in the Laboratory 
were analyzed by ESCA to determine the surface composition of both glasses. Table XIV presents the relative atomic composition for both surfaccs and the spectra are shown in Fig. 9. Because the bulk composition of the pilot scale and laboratory glasses prepared with simulated calcine is the same, time and cost factors dictated that unleached and leached samples of glass prepared with simulated calcine in the laboratory would not be investigated further by ESCA.

The surface of samples exposed to air are usually contaminated by adventitious carbon from the atmosphere which distorts some portions of the spectra. To eliminate this distortion, and any other surface contaminant on the glass surface, Ar ion-milling was used to remove approximately $50 \AA$ of the surface. Fig. 10 and Table XIV present data acquired after the ion-milling process. Nitrogen was detected on the surface of the pilot scale glass as a contaminant within $\checkmark 5-15 \AA$ of the surface. While the data demonstrate that the elemental surface composition of the glass prepared with simulated calcine is very close to that of the glass prepared with radioactive calcine, some differences are observed for the concentration levels of $\mathrm{F}, \mathrm{O}, \mathrm{Ca}, \mathrm{Sr}, \mathrm{Zn}$, and $\mathrm{Sn}$. The concentration level of $\mathrm{Ca}$ and $\mathrm{F}$ is slightly lower on the surface of glass prepared with radioactive calcine. The opposite is observed for the oxygen concentration level. The presence of $\mathrm{Zn}$ and $\mathrm{Sn}$ was observed only in the glass prepared with radioactive calcine and $\mathrm{Sr}$ was detected only in the pilot scale glass. The presence of $\mathrm{Zn}$ was determined by the $\mathrm{Zn} 2 \mathrm{p} 3 / 2$ peak located at $s 1022 \mathrm{eV}$ (off scale in Fig. 9).

The cut surface composition of the pilot scale melter glass prepared with simulated calcine is slightly different than the bulk composition of the pilot scale glass listed in Table XIII. The observed difference is due to reaction with laboratory air. This was confirmed by fracturing glass under air at room temperature and analyzing the surface after one-hour exposure to the ambient atmosphere. The air fractured surface composition was observed to be identical to that of the cut surface.

4. MCC-1 Leached Glass

ESCA spectra of surfaces of the MCC-1 28-day leached glasses prepared with simulated calcine in the pilot scale melter and prepared with radioactive calcine in the laboratory are presented in rig. 11. The leached surface of both glasses was very depleted in $\mathrm{Na}$ and slightly depleted in Si. Sn and F were depleted completely from the surface of glass containing radioactive calcine, while $F$ was depleted slightly from the surface of glass prepared with simulated calcine. In contrast, the leached surface was enriched with metals. In both cases, a significant increase in the content of $\mathrm{Zr}, \mathrm{Cu}$, and $\mathrm{Zn}$ was observed. Enrichment of $\mathrm{Cr}$ and $\mathrm{Fe}$ was observed only on the leached surface of glass prepared with simulated calcine. The spectra also show that $\mathrm{Sr}, \mathrm{B}$, and $\mathrm{Li}$ are depleted from the glass surfaces. The content of $\mathrm{Ca}$ on the leached surfaces, however, remained essentially unchanged with respect to the Ca concentration level of the respective unleached glass. 


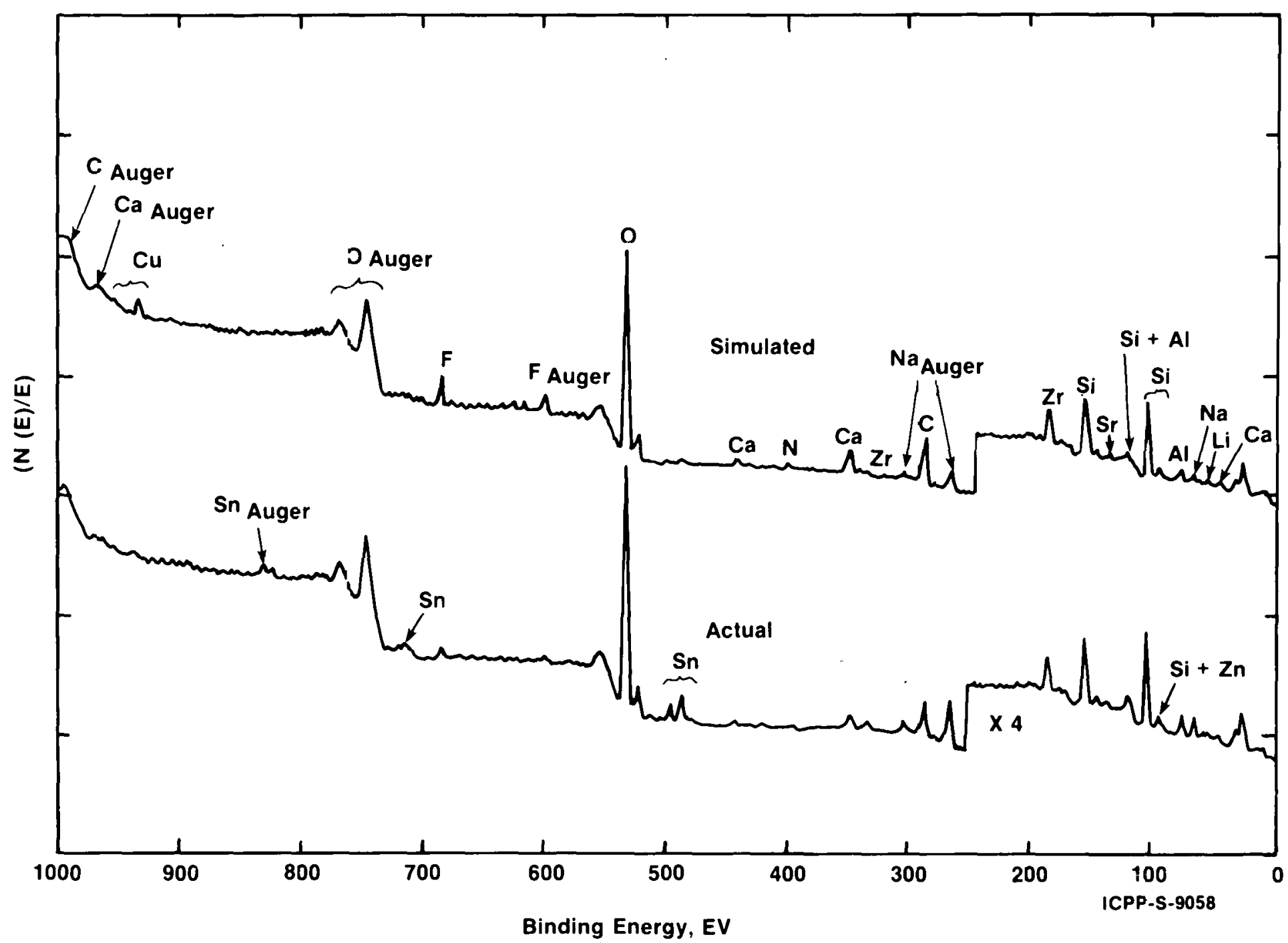

Figure 9. ESCA Spectra of Unleached Cut 127 Glass Prepared with Simulated Zirconia Calcine in the pilot Scale Melter and Prepared with Radioastive (Actual) Calcine in the Laboratory 


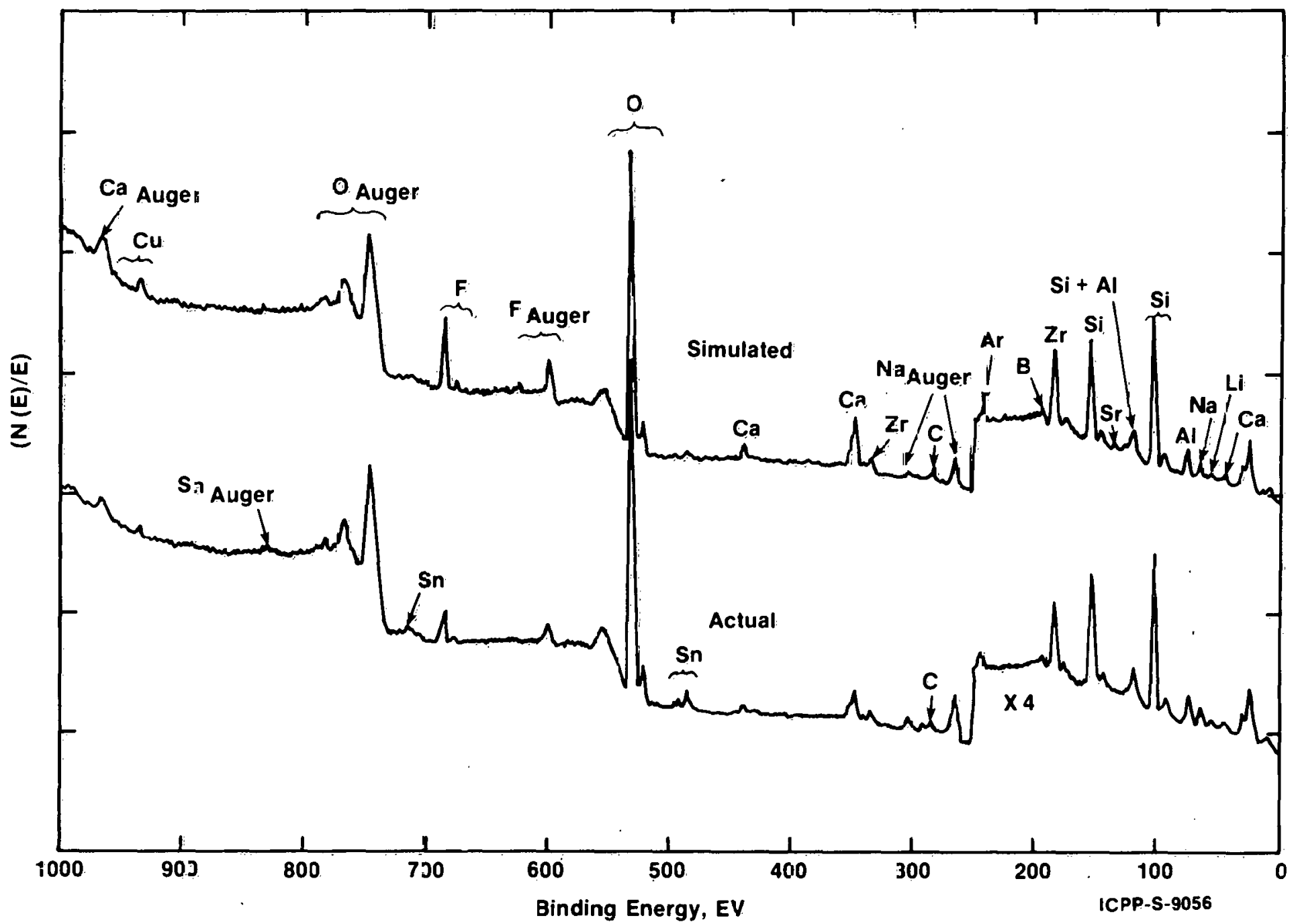

Figure 10. ESCA Spectré of UnTeached Cut 127 Glasș, Prepared with Simulated Zirconia Calcine in the Pilot Scale Melter and Prefared with Radioactive (Actual) Calcine in the Laboratory, after Removing Approximately $50 \mathrm{~A}$ of the Surface by $A=$ Ion Milling 


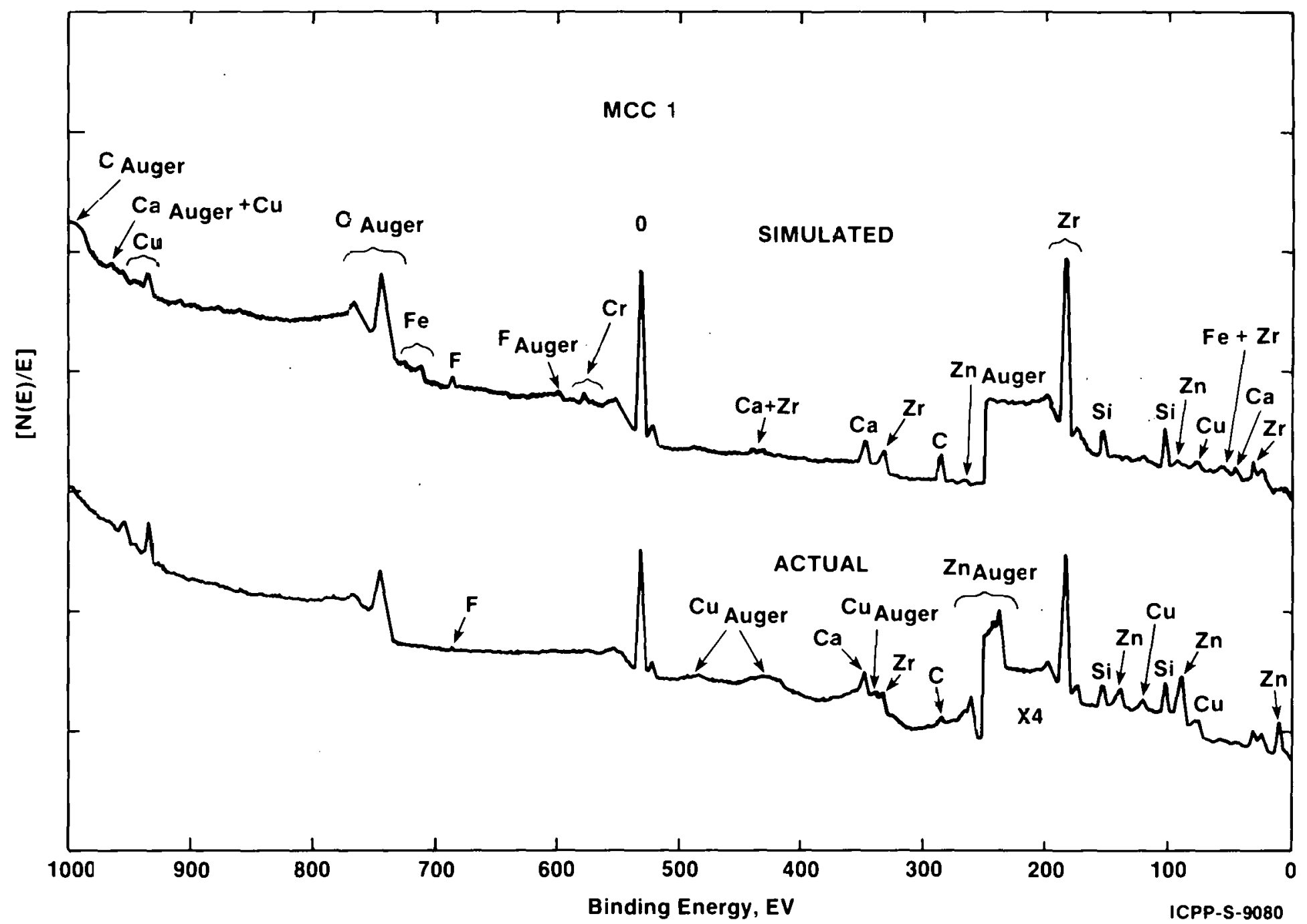

Figure 11. ESCA Spectra of the MCC-1 Leached Surface of 127 Glass Prepared with Simulated Zirconia Calcine in the Pilot Scale Melter and Prepared with Radioactive (Actual) Zirconia Calcine in the Laboratory 


\section{TABLE XIII}

BULK COMPOSITIONS OF 127 GLASS PREPARED WITH

SIMULATED CALCINE AS DETERMINED BY ESCA

\begin{tabular}{|c|c|c|}
\hline \multirow[b]{2}{*}{ Element } & \multicolumn{2}{|c|}{ Relative Atomic \% } \\
\hline & $\begin{array}{c}\text { Laboratory } \\
\text { Glass } \\
\end{array}$ & $\begin{array}{c}\text { Pilot Scale } \\
\text { Glass } \\
\end{array}$ \\
\hline 0 & 50.8 & 50.5 \\
\hline $\mathrm{Na}$ & 5.6 & 5.6 \\
\hline $\mathrm{Cu}$ & 0.4 & 0.2 \\
\hline$F$ & 9.2 & 9.8 \\
\hline $\mathrm{Ca}$ & 5.0 & 5.1 \\
\hline$N$ & 0.4 & 0.1 \\
\hline $\mathrm{Zr}$ & 1.3 & 1.3 \\
\hline $\mathrm{Li}$ & 5.6 & 5.6 \\
\hline$A 1$ & 2.0 & 2.3 \\
\hline $\mathrm{Si}$ & 15.8 & 15.8 \\
\hline$B$ & 4.0 & 3.7 \\
\hline $\mathrm{Sr}$ & $---a$ & $---a$ \\
\hline
\end{tabular}


UNLEACHED DIAMOND CUT SURFACE

COMPOS IT IONA OF 127 GLASS

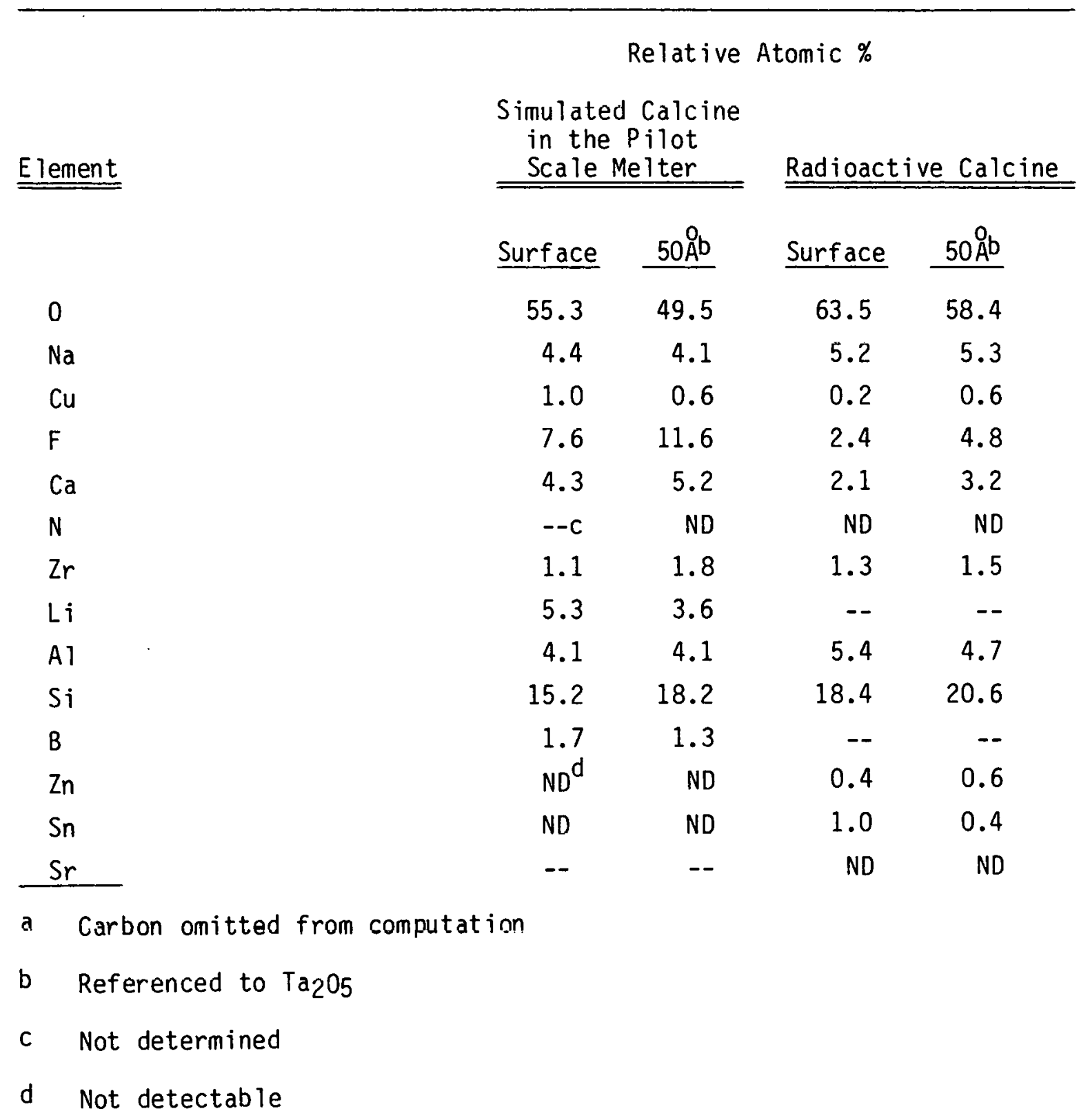


The analysis depth of ESCA for glass is approximately 5-30 $\AA$. To analyze at depths greater than the analysis depth, ion-milling was employed. Elemental depth profiles for key elements are given in Fig. 12 for the MCC-1 leached glasses. It was not possible to ion etch through the entire leach zone in a practical length of time due to the thickness of the leached layer $(\gg 2000 \mathrm{~A})$. For this reason, the leached surfaces were ionmilled only to a depth of $800 \AA$. In general, element concentrations are relatively constant in the $250-800 \AA$ region of the leached surface. This indicates that the interface between the leached and bulk glass is at a depth greater than $1000 \AA$. $Z$ inc is enhanced at the leached surface of both the simulated calcine and radioactive calcine glasses, with the largest concentration found for the glass containing radioactive calcine. In comparison to the unleached surface composition (Table XIV), depletion of $\mathrm{Na}, \mathrm{Sn}, \mathrm{Li}$, and $\mathrm{B}$ was observed with partial depletion of $S i$ and $A 1$. Fluorine was depleted from the surface of glass containing radioactive calcine and slightly depleted from the surface of glass containing simulated calcine. $\mathrm{Cu}$ and $\mathrm{Zr}$ were enriched, along with a slight enrichment of $\mathrm{Ca}$. The greatest concentration of enriched elements occurred between 250-800 $\AA$. The $\mathrm{Fe}$ and $\mathrm{Cr}$ profiles followed that of $\mathrm{Zn}$ in the simulated calcine glass. The only significant difference determined at a depth of $800 \AA$ between the leached surface of 127 glass prepared with either simulated or radioactive zirconia calcine is the $C a$ and $F$ concentration levels (Fig.'s 12 and 13). At this depth, fluorine is detectable only in the simulated calcinc glass and the concentration of $\mathrm{Ca}$ is significantly lower in the glass preparcd with radioactive calcine.

\section{B. SEM-EDX Analys is}

\section{Experimental}

Glass samples were coated with carbon by thermal evaporation and analyzed at room temperature by Energy Dispersive X-Ray (EDX) in combination with Scanning Electron Microscopy (SEM). Samples were not polished for quantitative analysis. The SEM-EDX system used was a AMRAY Model 1200 with a KEVEX Mode 17000 EDX system. The electron beam was operated at $15 \mathrm{KV}$ and rastered over a 500X area for all EDX data. Elements $L i, B$, and $F$ were not determined due to the poor sensitivity of EDX for these elements.

2. Un leached and MCC-1 Leached Glass

EDX quantitative data (Table XV) for 127 glass prepared with radioactive zirconia calcine in the laboratory, for glass prepared with simulated zirconia calcine in the laboratory and in the pilot scale melter show only slight differences between the surface of unleached and MCC-1 leached samples. In general, the 

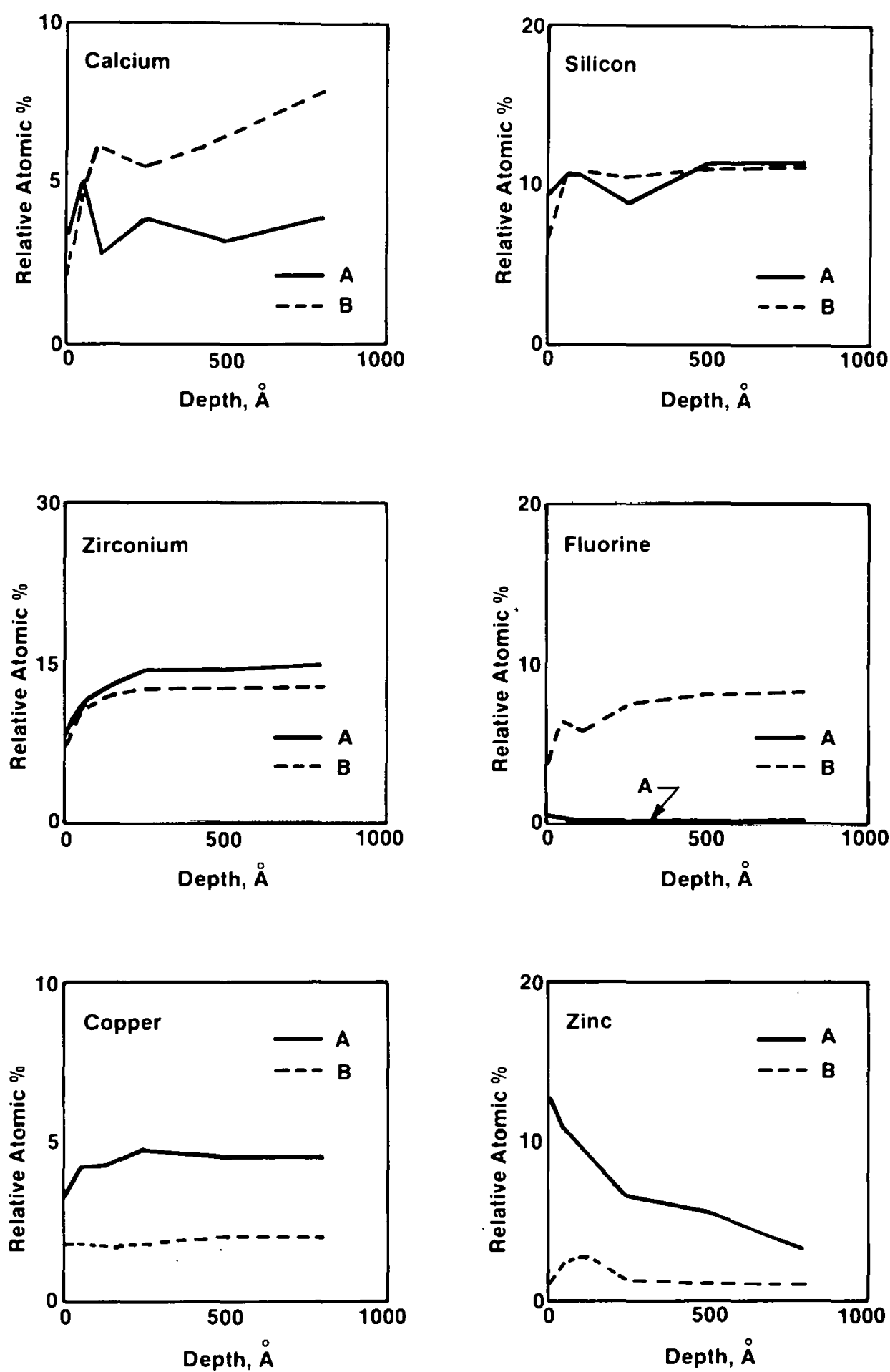

ICPP-S-9081

Figure 12. Depth Profiles of MCC-1 Leached Formula 127 Glass Prepared with Simulated Zirconia Calcine in the Pilot Scale Melter and Prepared with Radioactive (Actual) Calcine in the Laboratory; A) Radioactive Calcine, B) Simulated Calcirle; Depth scale Referenced to $\mathrm{Ta}_{2} \mathrm{O}_{5}$. 


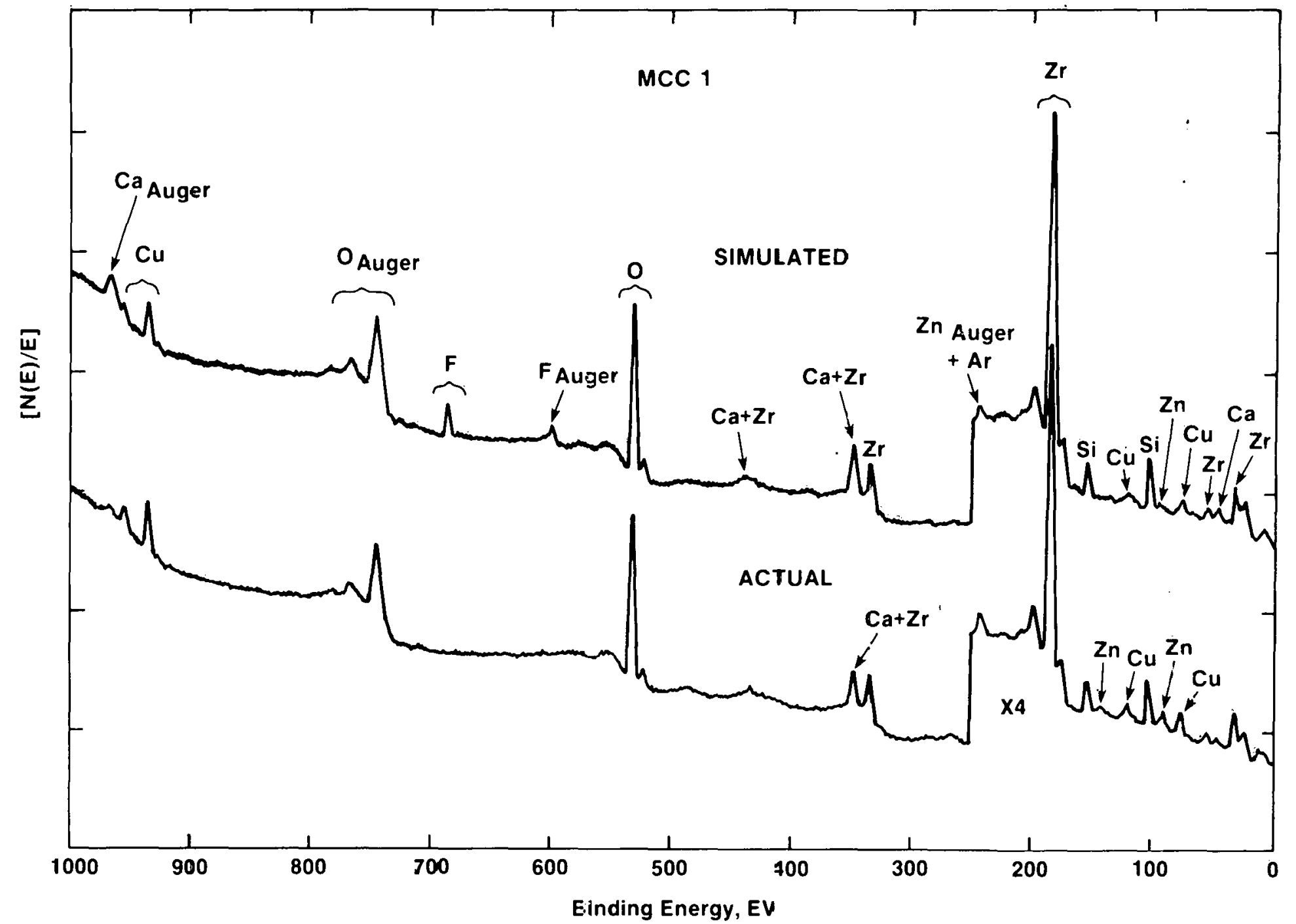

Figure 13. ESCA Spectra a: a Depth of $800 \AA$, of MCC-1 Leached 127

ICPP-S-9082 Glass Prepared with Simulated Zirconia Calcine in the Pilot Scale Mel-er and Prepared with Radioactive (Actua')

Calcine in the Laboratory. 
concentration of $\mathrm{Na}$ and $\mathrm{Al}$ is lower for the leached samples while the concentration of $\mathrm{Zr}$ and $\mathrm{Cu}$ is higher. The concentration of $\mathrm{Ca}$ and $\mathrm{Si}$ remained essentially unchanged between leached and unleached samples. Elements $\mathrm{Sr}$ and $\mathrm{Cs}$ were not detectable in any of the samples.

TABLE XV

FAR SURFACE COMPOSITION OF UNLEACHED AND MCC-1 LEACHED 127 GLASS PREPARED WITH EITHER SIMULATED OR RADIOACTIVE ZIRCONIA CALCINE AS DETERMINED BY SEM-EDX

Formula 127 Glass

(weight \%) ${ }^{a}$

$\underline{\mathrm{Na}} \quad \underline{\mathrm{Al}} \quad \underline{\mathrm{Si}} \quad \underline{\mathrm{Ca}} \quad \underline{\mathrm{Cu}} \quad \underline{\mathrm{Zr}} \quad \underline{\mathrm{Cr}} \quad \underline{\mathrm{Fe}} \underline{0}$

Radioactive

Calcine- $L^{b}$

$\begin{array}{llllllllll}\text { Un leached } & 6.21 & 6.47 & 26.8 & 7.85 & 1.38 & 6.51 & 0.11 & 0.32 & 44.36 \\ \text { Leachedc } & 5.06 & 5.27 & 27.08 & 7.24 & 1.28 & 9.91 & 0.12 & - & 44.05\end{array}$

Simulated

Calcine-L

Un leached

5.32

7.54

$23.78 \quad 12.38$

1.38

6.23

$0.18-$

43.20

Leached

2.71

6.54

$20.36 \quad 14.6$

3.11

11.67

0.24

40.77

Simulated

Calcine-PSMd

Un leached

6.38

$\begin{array}{lll}4.26 & 25.92 & 11.68\end{array}$

6.47

3.36

26.75

11.69

1.39

6.71

0.31

0.24

43.12

Leached

1.4

6.85

0.23

43.25

\footnotetext{
a $\quad \pm 0.2 \%$

b L: Laboratory Glass

c Leached: $M C C-1,28$ days

d PSM: Pilot Scale Melter Glass
}

SEM-EDX is more of a bulk analys is technique than a surface analys is

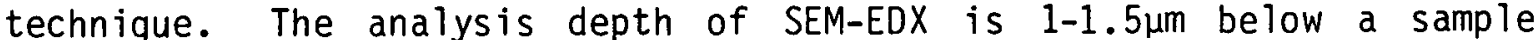
surface. For the leached data in Table XV, the majority of the EDX signal is from the substrate (bulk glass) below the leached layer. This is shown by a small difference between leached and unleached data along with only a small depletion of sodium from the leached samples. This indicates that the MCC-1 leached layer thickness is less than the SEM-EDX analysis depth of approximately $1 \mu \mathrm{m}$. 
The data in Table XV also demonstrates that the leached surface layer of glass prepared with radioactive calcine in the laboratory is about the same thickness as the leached layer of glass prepared with simulated calcine in the laboratory, since data for the two glasses is very similar. In addition, the data shows that the leached surface layer of these glasses is greater in thickness than that of glass prepared with simulated calcine in the pilot scale melter, because there is less difference in the leached and unleached data of the pilot melter glass than there is between the leached and unleached data of the other two glasses.

Elemental mapping indicated that all detectable elements except $\mathrm{Ca}$ and $F$ were homogeneously distributed throughout the analys is depth of 1-1.5 $\mathrm{\mu m}$ for each glass sample investigated. The exceptions of $\mathrm{Ca}$ and $F$ were observed in small areas (10-50um diameter) only in the glass prepared in the pilot scale melter. The glass composition adjacent to these areas of $\mathrm{Ca}$ and $\mathrm{F}$ concentration cuntained $\mathrm{Zr}$, $\mathrm{Na}, \mathrm{Al}, \mathrm{Si}, \mathrm{Cr}, \mathrm{Cu}$, $\mathrm{Fe}$ and $\mathrm{Ca}$ at levels similar to those of the glasses prepared on a laboratory scale (Table XVI). In these adjacenl areas the $C$ a and $F$ concentrations were significantly lower. The highly concentrated areas of $\mathrm{Ca}$ and

\section{TABLE XVI}

FAR SURFACE COMPOSITION OF HIGH AND LOW Ca AND F CONTENT AREAS AS DETERMINED BY SEM-EDX IN 127 GLASS PREPARED

IN THE PILOT SCALE MELTER, wt\%.

\begin{tabular}{|c|c|c|c|c|c|c|c|c|c|c|}
\hline & $\bar{F}$ & $\underline{\mathrm{Na}}$ & A] & $\underline{\mathrm{si}}$ & $\underline{C a}$ & $C_{r}$ & $\underline{\mathrm{Cu}}$ & $\underline{Z r}$ & $\mathrm{Fe}$ & $\underline{0}$ \\
\hline $\begin{array}{l}\text { Glass Adjacent to } \\
\mathrm{Ca} \text {, } \mathrm{F} \text { Concentration }\end{array}$ & $1.5^{\mathrm{a}}$ & 6.3 & 4.5 & 28.7 & 4.1 & 0.6 & 2.0 & 7.5 & 0.6 & 44.1 \\
\hline $\begin{array}{l}\text { Ca, F Concentration } \\
\text { Areas }\end{array}$ & 50.6 & - & - & - & 49.4 & - & - & - & - & - \\
\hline
\end{tabular}

a Background

$F$ are formations of $\mathrm{CaF}_{2}$ resulting from the slow cooling rate of the pilot scale melter glass. The presence of crystalline lat.2 in 127 glass has been confirmed by X-ray diffraction analysis in a previous study. 7 In that study it was determined that increased $\mathrm{CaF}_{2}$ crystallinity in 127 glass decreases its leachability.

Pilot scale melter glass was cooled at a sluwer rate than glass prepared on a laboratory scale. In this study SEM-EDX analysis determined that the leached surface layer of the pilot scale melter glass was thinner than that on the glasses prepared on a laboratory scale. ESCA analysis determined that the leached surface layer of the pilot scale melter glass was less depleted in $\mathrm{F}$ than that on the glasses prepared on a laboratory scale. These determinations and the identification of $\mathrm{CaF}_{2}$ centers of crystallization in the pilot scale melter glass samples by SEM-EDX analysis support the determination that the formation of crystalline $\mathrm{CaF}_{2}$ in 127 glass decreases its leachability. 


\section{CONCLUSIONS}

Based on the results obtained from applying the leach tests and solid state analytical techniques the following conclusions can be made.

\section{A. Leaching Studies}

1. In general the leaching properties of 127 glass prepared with radioactive calcine are similar, with respect to total mass, $\mathrm{Ca}, \mathrm{Cs}$ and $\mathrm{Sr}$ losses, to those of $127 \mathrm{glass}$ prepared with simulated calcine.

2. Actinides contained in the calcine were immobilized by vitrification to the degree that only insignificant quantities leached from the $127 \mathrm{glass}$. The low Pu-238 leach rate enhances the suitability of 127 glass as a final waste form because this rate is within an order of magnitude of those suggested for actinides from ceramics being proposed to immobilize Savannah River high-level wastes. 13,14

3. Of the independent test conditions investigated through a factorial design experiment only leaching temperature has a significant effect on total mass loss rate. This determination indicates that lower repository storage temperatures will result in decreased leachability of $127 \mathrm{glass.}$

4. Scaling up the quantity of glass prepared from laboratory scale to pilot melter scale does not significantly change the leaching properties of $127 \mathrm{glass}$. As indicated by the results of solid state analyses conducted in this study and by previously conducted leaching studies, 7 decreasing the melt cooling rate, such as done to the pilot scale melter glass, results in $\mathrm{CaF}_{2}$ crystallization which can be beneficial to product leachability. Thus in large scale 127 glass production melt cool down could be controlled to result in optimum product $\mathrm{CaF}_{2}$ crystallinity for improved product leach resistance.

\section{B. Solid State Studies}

1. Laboratory and pilot scale melter glasses prepared with simulated zirconia calcine have the same elemental bulk compositions as determined by ESCA.

2. In general, the composition, depletion and enhancement of elements on the leached surface of the 127 glass prepared with simulated zirconia calcine in the pilot scale melter are similar to those of 127 glass prepared with radioactive zirconia calcine in the laboratory suggesting that the leaching properties of both glasses should be similar. 
3. The interface between the leached layer and unleached glass is within 0.1-1.0um from the surface in samples subjected to the MCC-1 static leach test. The leached layer of the pilot scale melter glass, however, appears to be not as thick as that of the laboratory glass prepared with radioactive calcine. This may result from the presence of crystalline $\mathrm{CaF}_{2}$ in the pilot scale melter glass.

4. Fluorine depletion from the leached surface of the laboratory glass prepared with radioactive zirconia calcine is greater than that from the surface of the glass prepared in the pilot scale with simulated calcine suggesting the presence of a more leach resistant state of $F$ in the pilot melter product.

5. The concentrated areas of $\mathrm{Ca}$ and $\mathrm{F}$ observed on $1 \mathrm{y}$ in leached and unleached pilot scale melter glass are crystalline CaF2 formations ranging in size from about $10 \mu \mathrm{m}$ to 50 $\mu \mathrm{m}$ in diameter. 
VII. REFERENCES

1. R. E. Commander, G. E. Lohse, D. E. Black, and E. D. Cooper, Operation of the Waste Calcining Facility with Highly Radioactive Aqueous Waste, Report of the First Processing Campaign, ID0-14662 (June (966).

2. R. A. Kirkbride, Inventory of Calcined Wastes Stored at ICPP as of September 1979, ENICO-1044 (Se ptember 1980).

3. B. A. Staples, G. S. Pomiak, and E. L. Wade, Properties of Radioactive Calcine Retrieved from the Second Calcined Solids Storage Facility at ICPP, ICP-1189 (March 1979).

4. B. E. Paige, Leachability of Alumina Calcine Produced in the Idaho Waste Calcining Facility, IN-1011 (July 1966).

5. M. W. Wilding, and D. W. Rhodes, Leachability of Zirconia Calcine Produced in the Idaho Waste Calcining Facility, IN-1298 (June 1969).

6. D. Gombert II, H. S. Cole, and J. R. Berreth, Vitrification of HighLeve 1 ICPP Calcined Wastes, ICP-1177 (February 1979).

7. H. S. Cole, et. al., Properties of Vitrified ICPP Zirconia Calcine, ENICO-1038, ( Ju1 y 1980).

8. R. P. Schuman, Leach Testing of Idaho Chemical Processing Plant Final Waste Forms, ENICO-1064 (October 1980).

9. D. Gombert II, D. B. Chamberlain and E. L. Colton, Design and Installation of a Pilot-Plant to Vitrify ICPP Simulated Calcined HighLeve I Waste, ENICO-1087 (May 1981).

10. J. E. Mendel (editor) Nuclear Waste Materials Handbook Waste form Test Methods, DOE/TIC-1 1400 .

11. E. E. Hespe, "Leach Testing of Immobilized Radioactive Waste Solids - A Proposal for a Standard Method," Atomic Energy Review, 9, 195 (1971).

12. J. S. Hunter, Design of Experiments Course, Book 4 : Factorial Designs (1968).

13. J. Campbe11, et. al, "Immobilization of High-Level Defense Wastes in SYNROC: An Appraisal of Product Performance," Lawrence Livermore National Laboratory Rept. UCRL-85913 (1981).

14. J. Campbel1, et. al, "Immobilization of Savannah River High-Level Wastes in SYNROC: Resuits from Performance Tests," presented at the Materials Research Soc. Conf., Scientific Basis for Nuclear Waste Management, Boston, MA; Lawrence Livermore National Laboratory, Livermore, CA, UCRL-86753 (1981). 


\section{THIS PAGE \\ WAS INTENTIONALLY \\ LEFT BLANK}




\section{CALCULATION OF LEACHING PROPERTIES OF 127 GLASS}

This Appendix presents the calculation methods used in determining the leaching properties of 127 glass when subjected to the MCC-1, MCC-2, and Soxhlet leach tests. Leachate elemental concentrations were corrected by subtracting the corresponding blank concentrations.

I. The equation used to obtain total mass loss by application of MCC-1, MCC-2, or Soxhlet Leach Tests is:

$$
L_{m}=\frac{W_{j}-W_{f}}{S A}
$$

where:

$$
\begin{aligned}
& L_{m}=\text { mass of waste form loss per unit area }\left(\mathrm{g} / \mathrm{m}^{2}\right) \\
& W_{i}=\text { initial mass of specimen }(\mathrm{g}) \\
& W_{f}=\text { final mass of specimen }(\mathrm{g}) \\
& S A=\text { surface area of the un leached specimen }\left(\mathrm{m}^{2}\right)
\end{aligned}
$$

Total mass loss is converted to total mass loss rate by

$$
L R_{m}=\frac{L_{m}}{\text { days leached }}
$$

II. The equation used to obtain normalized elemental leaching $\left(\mathrm{g} / \mathrm{m}^{2}\right)$ by MCC-1, MCC-2, and Soxlet tests is:

$$
N L_{i}=\frac{C_{j}}{f_{j}(S A / N)}
$$

Where:

$\mathrm{NL}_{i}=$ the normalized mass of element " $i$ " lost per unit surface area of the speciment $\left(\mathrm{g} / \mathrm{m}^{2}\right)$ 
$f_{i}=$ mass fraction of element " $i$ " in the specimen when the experiment started

$\mathrm{SA}=$ surface area of the specimen $\left(\mathrm{m}^{2}\right)$

$C_{i}=$ concentration of element " $i "$ (mg/liter)

$V=$ volume of leachant $\left(\mathrm{mm}^{3}\right)$

Normalized elemental leaching is converted to leach rate (LR); by

$$
L R_{i}=\frac{N L_{i}}{\text { days leached }}
$$

III. The equation used for determining the radioisotopes is

$$
N_{i}=\frac{A_{i}}{A_{0}} W_{0} \frac{1}{S A}
$$

where $N_{i}$ and $S A$ are defined above and
A1 = activity of isotope " $i$ " in the leachate
$A_{0}=$ the original activity of the isotope in the specimen
$W_{0}=$ original mass of the specimen $(g)$ 


\section{CALCULATIONS FOR THE FACTORIAL DESIGN EXPERIMENT}

In addition to use in estimating main effects of variables, the interactions of variables to produce effects can be estimated by factorial design experiments. This analys is cannot be obtained by investigations which consist of applying one variable at a time. An advantage of applying a four or higher level factorial design experiment is that not only can estimates of the main effects and two factor interactions be obtained but that the error variations for these effects can be estimated through use of the three and four factor interactions.

A rapid method for obtaining the main effects and interactions is the Yates algorithm which was applied to total mass loss rate data obtained from performing this experiment. The Yates algorithm for this experiment is given in Table B-1. A description of performing it is given in "Design of Experiments Course," J. S. Hunter, No. 4, Factorial Designs, Westinghouse Electric Corporation, 1968. 
TABLE B-1

YATES ALGORITHM FOR FACTORIAL DESIGN EXPERIMENT

\begin{tabular}{|c|c|c|c|c|c|c|}
\hline $\begin{array}{l}\text { Test } \\
\text { No. }\end{array}$ & $\begin{array}{l}\text { Total Mass } \\
\text { Loss Rate } \\
\mathrm{g} / \mathrm{m}^{2} \text {. day }\end{array}$ & Col. 1 . & $\therefore$ Col. 2 & Col. 3 & Col. $4^{\circ}$ & $\begin{array}{c}\text { Est. } \\
\text { Effects }\end{array}$ \\
\hline 1 & 0.04 & 0.68 & 1.10 & 1.49 & 3.69 & $0.23=\overline{\bar{Y}}$ \\
\hline 2 & 0.64 & 0.42 & 0.39 & 2.20 & 2.73 & $0.34 \times 1$ \\
\hline 3 & 0.08 & 0.22 & 1.80 & 1.01 & -1.56 & $-0.20 \quad \times 2$ \\
\hline 4 & 0.34 & 0.17 & 0.40 & 1.72 & -1.55 & $-0.19 \times 1 \times 2$ \\
\hline 5 & 0.06 & 1.53 & 0.86 & -0.32 & -2.11 & $-0.26 \times 3$ \\
\hline 6 & 0.16 & 0.27 & 0.15 & -1.24 & -2.03 & $-0.25 \times 1 \times 3$ \\
\hline 7 & 0.06 & 0.19 & 1.52 & -0.39 & 1.48 & $-0.19 \times 2 \times 3$ \\
\hline 8 & 0.11 & 0.21 & 0.20 & -1.16 & 1.57 & $0.20 \times 1 \times 2 \times 3$ \\
\hline 9 & 0.08 & 0.60 & -0.26 & -0.71 & 0.71 & $.09 \times 4$ \\
\hline 10 & 1.45 & 0.26 & -0.06 & -1.40 & 0.71 & $.09 \times 1 \times 4$ \\
\hline 11 & 0.06 & 0.10 & -1.26 & -0.71 & -0.92 & $.12 \times 2 \times 4$ \\
\hline 12 & 0.21 & 0.05 & 0.02 & -1.32 & -0.77 & $-0.10 \times 1 \times 2 \times 4$ \\
\hline 13 & ก.06 & 1.37 & 0.34 & 0.20 & -0.69 & $-0.09 \times 3 \times 4$ \\
\hline 14 & 0.13 & 0.15 & -0.05 & 1.28 & -0.61 & $-0.08 \times 1 \times 3 \times 4$ \\
\hline 15 & 0.04 & 0.07 & -1.22 & 0.29 & 1.08 & $0.14 \times 2 \times 3 \times 4$ \\
\hline 16 & 0.17 & 0.13 & 0.06 & 1.28 & 0.99 & $0.12 \times 1 \times 2 \times 3 \times 4$ \\
\hline
\end{tabular}

where effect $x 1=$ Leaching Temperature $\left(40^{\circ} \mathrm{C}, 900 \mathrm{C}\right)$.

$x_{2}=$ Leachant Type (Distilled Deionized H2O, MCC-1 Brine)

$x_{3}=$ Sample Surface Area to Leachant Volume $(1: 10)$

$x_{4}=$ Calcine Type Used in Preparation (simulated, actual) 
Assuming that the three factor $(\times 1 \times 2 \times 3, \times 1 \times 2 \times 4, \times 1 \times 3 \times 4, \times 2 \times 3$ $\times 4)$ interactions and the four factor $\left(x_{1} \times 2 \times 3 \times 4\right)$ interactions are negligible, then the error for the main effects ( $\left.x_{1}, x_{2}, x_{3}, x_{4}\right)$ and two factor interactions $\left(x_{1} \times 2, x_{1} \times 3, x_{2} \times 3, x_{1} \times 4, x_{2} \times 4, x_{3} \times 4\right)$ can be estimated. This analysis of variance using the three and four factor interactions permits application of the entire design without replication. The analysis of variance is performed below on the three largest effects $x_{1}, x_{3}$, and $x_{1}, x_{3}$ obtained from Yates algor ithm above. This application, also described in "Design of Experiments" indicates that within the $95 \%$ confidence interval on $7 y$ the $x_{1}$ main effect, the leaching temperature effect is significant on the total mass loss rate.

Sum of Squares (SSQ)

SSQ $\times 1 \times 2 \times 3$

SSQ $\times 1 \times 2 \times 4$

SSQ $\times 1 \times 3 \times 4$

SSQ $\times 2 \times 3 \times 4$

SSQ $x_{1} \times 2 \times 3 \times 4$

$$
\frac{(16)(-0.20)^{2}}{4}=0.160
$$$$
\frac{(16)(0.1)^{2}}{4}=0.040
$$

$\frac{(16)(0.08)^{2}}{4}=0.025$

$$
\frac{(16)(0.14)^{2}}{4}=0.078
$$

$$
\frac{(16)(0.12)^{2}}{4}=0.058
$$

$$
=0.361
$$

\section{Degrees of Freedom}

1

1

1

Residua I SSQ (RSSQ)

$5 s^{2}=.072+\sigma^{2}$

For the 95\% Confidence Level with 5 degrees of freedom,

$$
\text { effect: } \pm t \underline{\underline{0.025 .5}} \sqrt{\frac{N\left(s^{2}\right)}{4}}=\text { effect } \pm 2.571 \sqrt{\frac{4(.072)^{2}}{16}}= \pm .35
$$

for $\times 1$ effect: $\frac{(2.73)^{2}}{16}=0.466 \frac{0.466}{\frac{\text { RSSQ }}{5}}=6.47 \pm 0.35 F_{1}, 5>6.61=0.05$

for $\times 3$ effect: $\frac{(-2.11)^{2}}{10}=0.278 \frac{0.278}{\frac{\text { RSSQ }}{5}}=3.86 \pm 0.35 F_{1}, 5>6.61=0.05$

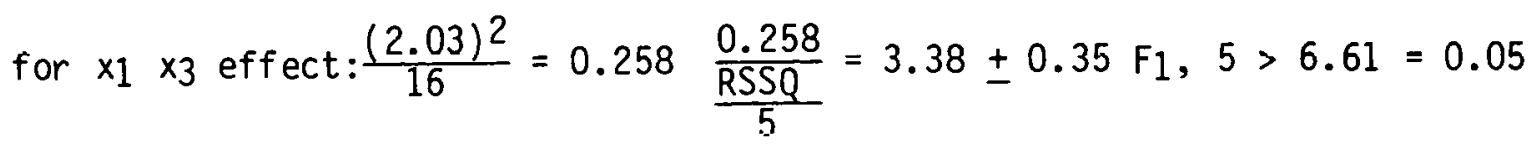

